\title{
Terpenoids from Marine Soft Coral of the Genus Xenia in 1977 to 2019
}

\author{
Shean-Yeaw Ng ${ }^{1}{ }^{(0)}$, Chin-Soon Phan ${ }^{1}\left(\mathbb{D}\right.$, Takahiro Ishii ${ }^{2}{ }^{(0)}$, Takashi Kamada ${ }^{3}$, \\ Toshiyuki Hamada ${ }^{4}$ and Charles Santhanaraju Vairappan ${ }^{1, *(D)}$ \\ 1 Laboratory of Natural Products Chemistry, Institute for Tropical Biology and Conservation, \\ Universiti Malaysia Sabah, Kota Kinabalu 88400, SBH, Malaysia; sheanyeaw@ums.edu.my (S.-Y.N.); \\ yuna123@hotmail.my (C.-S.P.) \\ 2 Department of Bioscience and Biotechnology, Faculty of Agriculture, University of the Ryukyus, 1 Senbaru, \\ Nishihara, Okinawa 903-0213, Japan; ishiit@agr.u-ryukyu.ac.jp \\ 3 Department of Materials and Life Science, Faculty of Science and Technology, Shizuoka Institute of Science \\ and Technology, 2200-2 Toyosawa, Fukuroi, Shizuoka 437-8555, Japan; takashi.kamada800@gmail.com \\ 4 Graduate School of Science and Engineering, Kagoshima University, 1-21-35 Korimoto, \\ Kagoshima 890-0065, Japan; thamada@sci.kagoshima-u.ac.jp \\ * Correspondence: csv@ums.edu.my; Tel.: +60-88-320-000 (ext. 2353); Fax: +60-88-320-291
}

Received: 17 October 2020; Accepted: 12 November 2020; Published: 18 November 2020

\begin{abstract}
Members of the marine soft coral genus Xenia are rich in a diversity of diterpenes. A total of 199 terpenes consisting of 14 sesquiterpenes, 180 diterpenes, and 5 steroids have been reported to date. Xenicane diterpenes were reported to be the most common chemical skeleton biosynthesized by members of this genus. Most of the literature reported the chemical diversity of Xenia collected from the coral reefs in the South China Sea and the coastal waters of Taiwan. Although there was a brief review on the terpenoids of Xenia in 2015, the present review is a comprehensive overview of the structural diversity of secondary metabolites isolated from soft coral genus Xenia and their potent biological activity as reported between 1977 to 2019 .
\end{abstract}

Keywords: marine soft corals; Xenia sp.; natural products; terpenes; bioactivity

\section{Introduction}

Marine-derived terpenoids have attracted the interest of natural product chemists around the world, leading to the discovery of many novel chemical skeletons and possible lead drug candidates. In recent years, various species of marine soft corals from Taiwan and the South China Sea have been chemically investigated for their chemical diversity and potential as bioactive compounds [1-8]. Among them, marine soft coral of the genus Xenia (Alcyonacea, Xeniidae) has afforded numerous new terpenoids with diverse structures and few biological activities. These terpenoids are mainly dominated by xenicane-type or xenia diterpenoids. Some of these diterpenes have also been found in the alcyonacean soft corals such as Anthelia glauca [9], Asterospicularia laurae [10], Capnella thyrsoidea [11], Eleutherobia aurea [12], Heliopora coerulea [13], and Sinularia gibberosa [14] and in several gorgonian species $[15,16]$. In this context, a total of 199 terpenes consisting of 14 sesquiterpenes, 180 diterpenes, and 5 steroids has been reported to date. These terpenes were isolated from species of the soft coral Xenia, including X. blumi, X. crassa, X. elongata, X. faraunensis, X. florida, X. lilielae, X. macrospiculata, X. membranacea, X. novae-britanniae, X. obscuronata, X. puerto-galerae, X. stellifera, X. umbellata, X. viridis, and Xenia sp., many of which were collected at Green Island in Taiwan, regions of Kagoshima and Okinawa in Japan, Gulf of Eilat at the Red Sea, Townsville in Australia, and Sarcelle Pass south of New Caledonia. A review about Xenia terpenoids was reported in 2015 that listed terpenoids and their 
anticancer properties. However, in an effort to better understand the chemistry of marine-derived natural products from the soft coral genus Xenia and their bioactive potentials, this review summarizes the collection locations and chemical diversity of specimens and the biological properties of this genus that have been obtained from literature published between 1977 and 2019 (1997 to 2014 were re-reviewed).

\section{Diterpenes}

Diterpenes are synthesized by four isoprene units, and their basic structure starts with the molecular formula $\mathrm{C}_{20} \mathrm{H}_{32}$. Many have a variety of modifications such as methylation, acetylation, hydroxylation, epoxidation, and oxygenation, giving them additional carbon and oxygen atoms in their molecular formula. Xenicane diterpenes contain a cyclononane skeleton. Figure 1 shows the three structurally different types of xenicane diterpenes: xenicins (possessing a 2-oxabicyclo[7.4.0]tridecane ring system) [17], xeniolides (the lactone derivatives of xenicins) [18], and xeniaphyllanes (containing a bicyclo[7.2.0]undecane ring system) [19]. Subsequently, more groups were categorized, such as floridicins (tricarbocyclic diterpenoid) [20], xeniaethers (bearing a oxabicyclo[7.3.0] undecane ring system) [21], and azamilides (having an opened A-ring with the nine-membered carbocyclic skeleton acylated with a series of C16-C20 saturated fatty acids) [22]. Since then, more novel carbon skeletons have been discovered in the 21st century such as blumiolide-A with cyclooctane system of xeniolide [23], umbellactal with $\gamma$-lactone fused to a bicyclo[4.3.0]nonane ring system [24], xenibellol A with tetracyclic system [25], and xenibellal with norditerpenoid of cyclononane system [26].

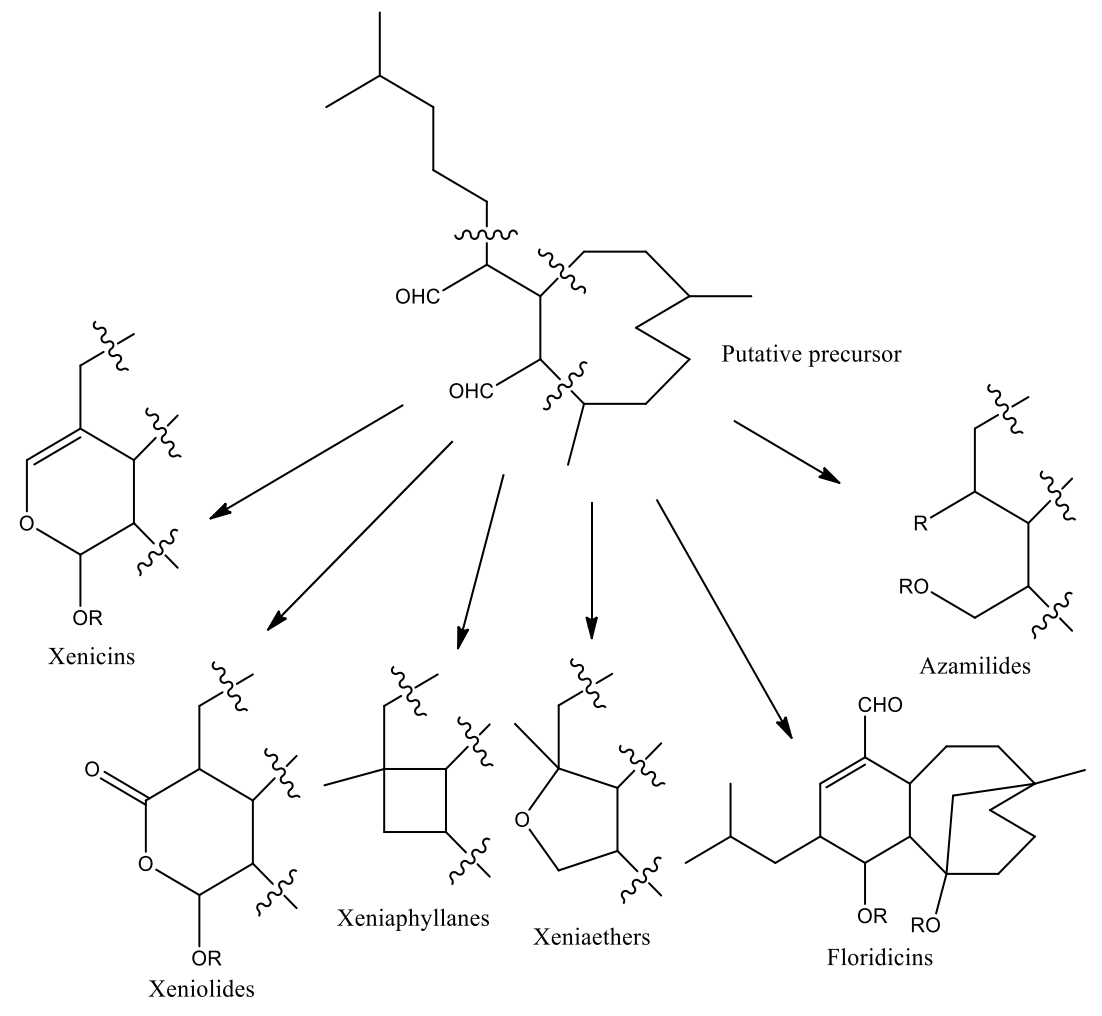

Figure 1. Diversity of chemical skeletons discovered from soft coral genus Xenia.

\subsection{Xenia Blumi}

In 2005, eight new diterpenoids, namely blumiolides A-C (1-3), 9-deoxy-isoxeniolide-A (4), 9-deoxy-7,8-epoxy-isoxeniolide-A (5), 9-deacetoxy-7,8-epoxy-13-epi-xenicin (6), 9-deoxy-7,8-epoxyxeniolide-A (7), and blumicin-A (8) were isolated from X. blumi collected from Green Island, Taiwan [23]. Blumiolide-A was reported as a new skeleton of xeniolide with cyclooctane system, and blumiolide-C 
(3) showed potent cytotoxicity against HT-29 colorectal cancer and P-388 murine leukemia cell lines at $\mathrm{ED}_{50} 0.5$ and $0.2 \mu \mathrm{g} / \mathrm{mL}$, respectively (Figure 2) [23].

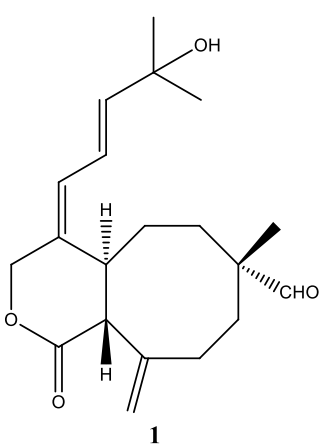

1<smiles>C=C1CC[C@]2(C)O[C@@]2(C)CC[C@H]2/C(=C\C=C\C(C)(C)O)C(=O)OC[C@H]12</smiles>

7

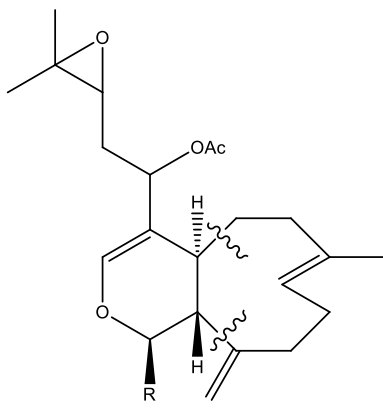

$12 \mathrm{R}=\mathrm{OAc}$ $16 \mathrm{R}=\mathrm{OMe}$<smiles>C=C1CC[C@@]2(CC[C@@H](O)[C@@H]1C)C(=C/C=C/C(C)(C)O)COC(=O)[C@@]2(C)C(C)C</smiles><smiles>C=C1CCCCC[C@]2(C)COC(=O)/C(=C\C=C\C(C)(C)O)[C@]12C</smiles>

3 9-ketone of 4

4

5 7,8-epoxide of 4

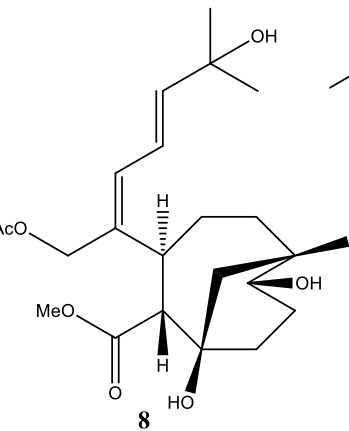<smiles>CC(C)=O</smiles>

$-$<smiles>CC(C)=CC/C=C(/CO)[C@H](C)C(C)(C)C(=O)O</smiles>

13

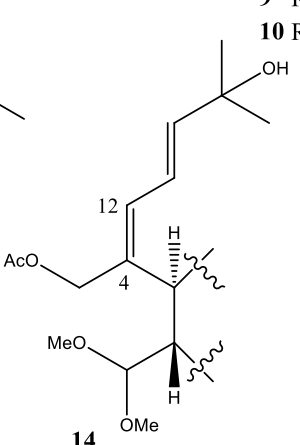

$154,12-Z$ of $\mathbf{1 4}$

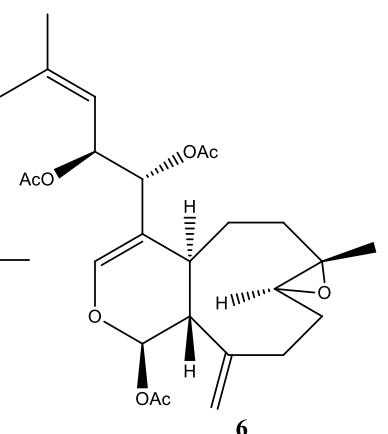<smiles>C=C1CC/C(C)=C\CC[C@]2(/C=C\CC=C(C)C)COC(=O)[C@]12C</smiles>

11

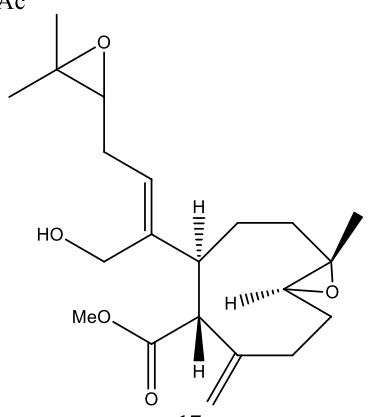

17

Figure 2. Structures of compounds 1-17.

\subsection{Xenia Crassa}

One new diterpenoid, 9-deacetoxyxenicin (9), was isolated from X. crassa collected at John Brewer Reef, Australia [27] (Figure 2).

\subsection{Xenia Elongata}

In 1977, the first representative of the xenicins, xenicin (10), was isolated from X. elongata collected at Heron Island, Australia [17]. After 18 years, one new diterpenoid, deoxyxeniolide B (11) was isolated from X. elongata collected from Nichinan Coast, Miyazaki Prefecture, Japan [28]. This compound exhibited ichthyotoxicity against mosquito fish (Orizias latipes) at $\mathrm{LC}_{100} 15 \mathrm{ppm}$ within $1 \mathrm{~h}$. In 2007, four new diterpenoids (12-15) without given names were isolated from X. elongata cultured at Rutgers University [29]. Furthermore, compound 12 was found to be able to induce apoptosis in MCF 7 (breast carcinoma) cell lines. In 2014, two new diterpenoids (16 and 17) without given names were isolated from X. elongata, purchased from Ocean Reef Aquariums and cultured at Rutgers University [30]. In addition, compound 17 showed inhibition of histone deacetylase (HDAC6) with $\mathrm{IC}_{50} \sim 80 \mu \mathrm{M}$ (Figure 2) [30]. 


\subsection{Xenia Faraunensis}

In 1994, three new diterpenoids, xeniafaraunols A and B $(\mathbf{1 8 , 1 9 )}$ and faraunatin $(\mathbf{2 0})$, were isolated from X. faraunensis collected from the Red Sea [31]. These three compounds 18-20 exhibited cytotoxic activities against P-388 murine leukemia cells $\left(\mathrm{IC}_{50}=1.2 \mu \mathrm{g} / \mathrm{mL}\right.$ ) (Figure 3) [31].<smiles>C=C1CCC(C)=CCC[C@]2(C)C(C=O)=C[C@H](C=C(C)C)[C@@H](O)[C@@]12C</smiles><smiles>C[C@@H]1CC[C@@H](O)[C@H]2C[C@H]1/C(=C/C(C)(C)O)C=C(C=O)[C@H]2O</smiles>

24<smiles>[R]C(C)(C)/C=C/C=C1/COC(=O)[C@H]2[C@H]1[C@@]1(C)CC[C@@H](O)[C@@](C)(CC1)[C@@H]2O</smiles>

$26 \mathrm{R}=\mathrm{OH}$ $27 \mathrm{R}=\mathrm{H}$<smiles>CC(C)=CCC(O)[C@@]1(C)CCC=CCC[C@H]1C=C(C)C</smiles>

20

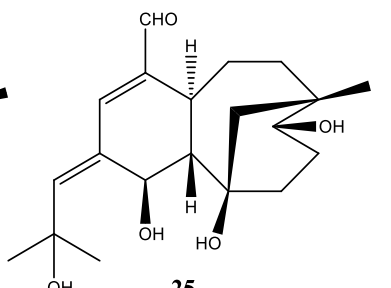<smiles>[R]C(C)(C)/C=C/C=C1/COC(=O)[C@@H]2[C@@H](C)CC[C@@H]3O[C@]3(C)CC[C@H]12</smiles>

$28 \mathrm{R}=\mathrm{H}$

$29 \mathrm{R}=\mathrm{OH}$

$30 \mathrm{R}=\mathrm{OOH}$

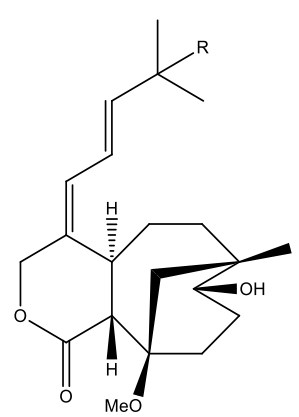

$33 \mathrm{R}=\mathrm{H}$

$44 \mathrm{R}=\mathrm{OH}$

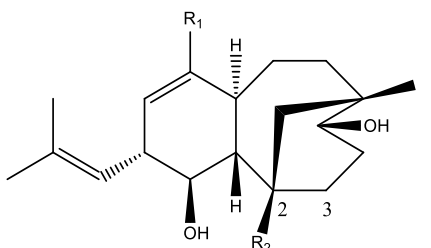

$21 \mathrm{R}_{1}=\mathrm{CHO} \mathrm{R}_{2}=\mathrm{OH}$

$22 \mathrm{R}_{1}=\mathrm{CHO} \mathrm{R}_{2}=\mathrm{OMe}$

$23 \mathrm{R}_{1}=\mathrm{CH}_{2} \mathrm{OH} \mathrm{R} \mathrm{R}_{2}=\mathrm{OH}$

$34 \mathrm{R}_{1}=\mathrm{CHO}$ and 2,3-epoxide

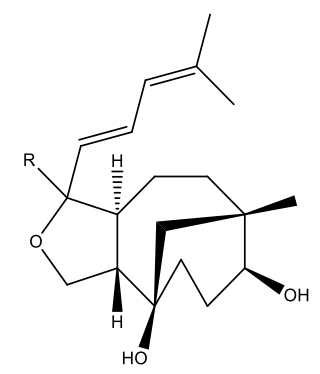

$31 \mathrm{R}=\beta-\mathrm{CH}_{2} \mathrm{OH}$ $32 \mathrm{R}=\alpha-\mathrm{CH}_{2} \mathrm{OH}$

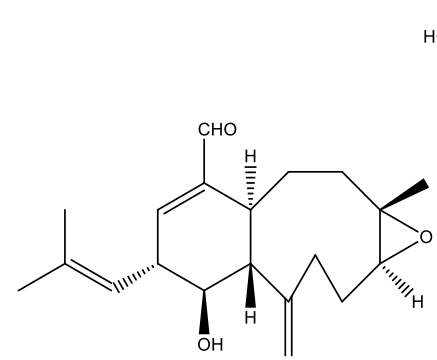

35<smiles>C=C1CC[C@H](O)/C(C)=C/C[C@H]2/C(=C\C=C\C(C)C)COC(=O)[C@]12C</smiles><smiles>C=C1CC[C@@H]2O[C@]2(C)CC[C@H](/C(=C\C=C\C(C)(C)O)OC(C)=O)[C@H]1C(C)=O</smiles>

36

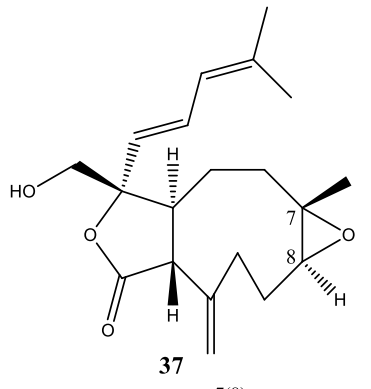

$41 \Delta^{7(8)}$ of $\mathbf{3 7}$

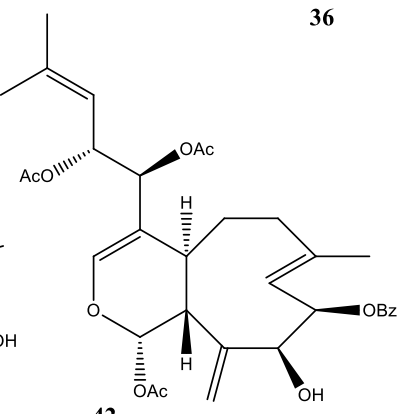

42

43 7,8- $\beta$-epoxide of $\mathbf{4 2}$

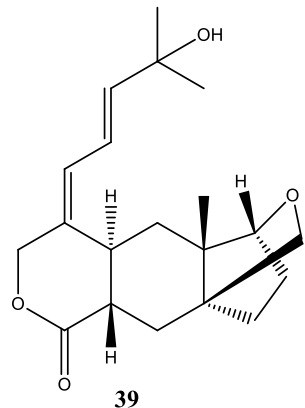

39

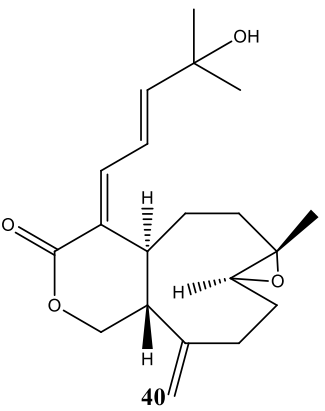

Figure 3. Structures of compounds 18-44. 


\subsection{Xenia Florida}

In 1994, a new class of tricarbocyclic diterpenoid, floridicin (21), was isolated from X. florida collected at Bonotsu, Kagoshima Prefecture, Japan [20]. This was the first diterpenoid found possessing an aldehyde group in a soft coral Xenia sp. This was followed by the isolation of four new tricarbocyclic diterpenoids, 2-O-methylfloridicin (22) and floridicins A-C (23-25), from X. florida collected at Bonotsu, Kagoshima Prefecture, Japan [32]. In 1998, seven new diterpenoids, florlides A-E (26-30) and florethers A and B (31 and 32), were isolated from X. florida collected at Bonotsu, Kagoshima Prefecture, Japan [33]. In 2000, six new diterpenoids, namely 11-O-methylflorlide A (33), 2 $\beta$-epoxyfloridicin (34), xeniafaraunol B (35), and florlides F-H (36-38), were isolated from X. florida collected at Bonotsu, Kagoshima Prefecture, Japan [34]. In 2005, three new diterpenoids, xeniolactones A-C (39-41), were isolated from X. florida collected at Green Island, off Taiwan [35]. In 2006, three new diterpenoids, florxenilides A-C (42-44), were isolated from X. florida collected at Green Island, off Taiwan [36]. The florxenilide B (43) showed strong cytotoxicity against Hepa 1-6 human liver carcinoma cells at $\mathrm{ED}_{50} 1.88 \mu \mathrm{g} / \mathrm{mL}$ (Figure 3) [36].

\subsection{Xenia Lilielae}

In the only report for this species, two new diterpenoids, 4,14-diepoxyxeniaphyllene (45) and 4,14-diepoxy-xeniaphyllenol-A (46), were isolated from X. lilielae collected from the Gulf of Eilat, the Red Sea [37] (Figure 4).

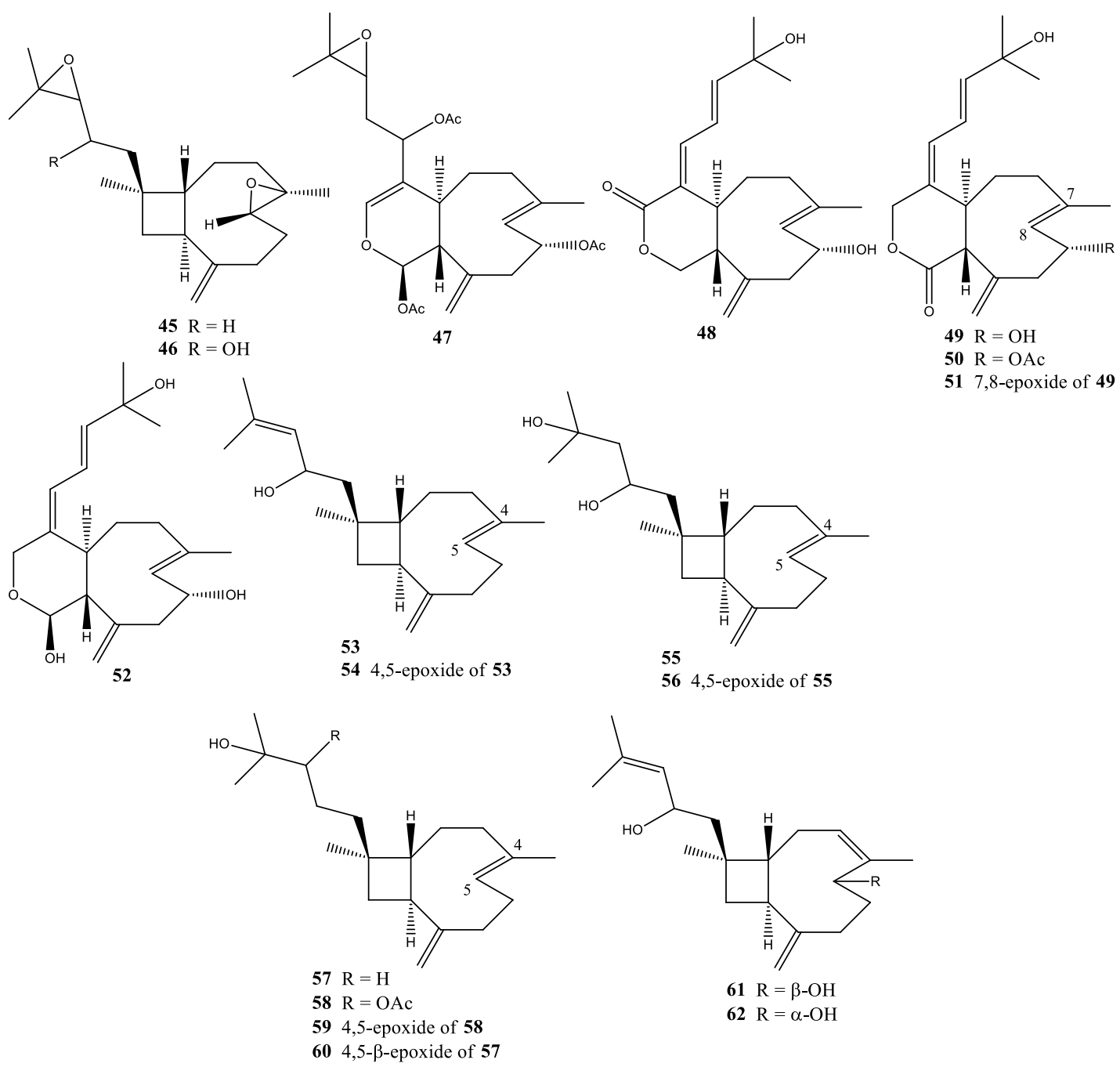

Figure 4. Structures of compounds 45-62. 


\subsection{Xenia Macrospiculata}

One year after the discovery of xenicin, a second compound of xenicin, xeniculin (47), was isolated from X. macrospiculata collected at the Gulf of Eilat, the Red Sea [38]. In the same year, two new xeniolides, xeniolides A and B (48 and 49), were reported from X. macrospiculata collected at the Gulf of Eilat, the Red Sea [18]. In 1980, xeniolide-B 9-acetate (50), 7,8-epoxyxeniolide-B (51), 4,5-epoxyxeniaphyllenol (54), isoxeniaphyllenol (55), xeniaphyllandiol 14-acetate (58), and 4,5-epoxy-14,15-xeniaphyllandiol (59) were first isolated from X. macrospiculata collected at the Gulf of Eilat, the Red Sea [19]. In the same year, xenialactol (52), xeniaphyllenol (53), 4,5-epoxyisoxeniaphyllenol (56), and 14,15-xeniaphyllandiol (57), were first discovered in both X. obscuronata from the Gulf of Suez (Red Sea) and X. macrospiculata from the Gulf of Eilat (Red Sea) [19]. In 1983, 4,5-epoxyxeniaphyllan-14,15-diol (60) was isolated from X. macrospiculata, X. obscuronata, and X. lilielae collected at the Gulf of Eilat, the Red Sea [37]. Xeniaphyllenols B and C (61 and 62) were also isolated from X. macrospiculata (Gulf of Eilat, the Red Sea) by the same research group [37] (Figure 4).

\subsection{Xenia Membranacea}

In 1987, two new diterpenoids, havannahine (63) and desoxyhavannahine (64), were isolated from X. membranacea collected at Sarcelle Pass, south of New Caledonia [39]. In 1988, four new diterpenoids, namely havannachlorhydrine-11(19) (65), havannachlorhydrine-7(18) (66), havannadichlorhydrine7(18),11(19) (67), and désaceétyl-13 havannachlorhydrine-11(19) (68), were isolated from X. membranacea collected at Sarcelle Pass, south of New Caledonia [40]. To date, these compounds 65-68 are the only halogen-based diterpenes found in soft coral Xenia sp. In 1989, a pair of new diastereomeric diterpenoids, 11,19-desoxyhavannahine (69) and 7,8,9-epi-11,19-desoxyhavannahine (70), were isolated from X. membranacea collected at Sarcelle Pass, south of New Caledonia [41]. In 1990, 17 new diterpenoids, namely acetoxy-19-havannabol-11 (71), chloro-18 acetoxy-19 havannadiol-7,11 (72), havannabol-7 (73), chloro-19 havannadiol-7,11 (74), epi-8,9 deoxy-11,19 havannachlorhydrine-7,18 (75), bis-deoxy-7,18,11,19 havannahine (76), desacetyl-9 epoxy-7,8 epi-13 xénicine (77), desacetyl-9 acetoxy-18 epoxy-7,8 epi-13 xenicine (78), desacetyl-9 hydroxy-6 epi-13 xenicine (79), xenione (80), acetoxy-18 xenione (81), desacetoxy-9 epi-13 xenicine (82), desacetoxy-9 oxo-9 epi-13 xenicine (83), acide branacenoïque (84), branacennoate de metyhle (85), branacenal (86), and diepoxy-7(8),10(11) dichloro-18,19 isoxeniolide A (87), were isolated from X. membranacea collected at Sarcelle Pass, south of New Caledonia [42]. However, the stereochemistry of these compounds has remained undetermined to date (Figure 5).

\subsection{Xenia Novae-Britanniae}

In 1979, three new xenicin-related diterpenoids were isolated from X. novae-britanniae collected at Laing Island, Papua New Guinea: 13-epi-9-desacetylxenicin (88), isoxeniolide-A (89), and 7,8-oxidoisoxeniolide-A (90) [43]. Besides, a total of seven new xenicane-type diterpenoids, novaxenicins A-D (91-94) and xeniolides I-K (95-97), were isolated from X. novae-britanniae collected at Kitagamwa, southern Kenya, in 2006 [44]. Furthermore, novaxenicin B (92) induced apoptosis in transformed HEK-293 mammalian cells at a concentration of $1.25 \mu \mathrm{g} / \mathrm{mL}$, and xeniolide I (95) showed antibacterial activity at a concentration of $1.25 \mu \mathrm{g} / \mathrm{mL}$ against Escherichia coli and Bacillus subtilis (Figure 6) [44]. 

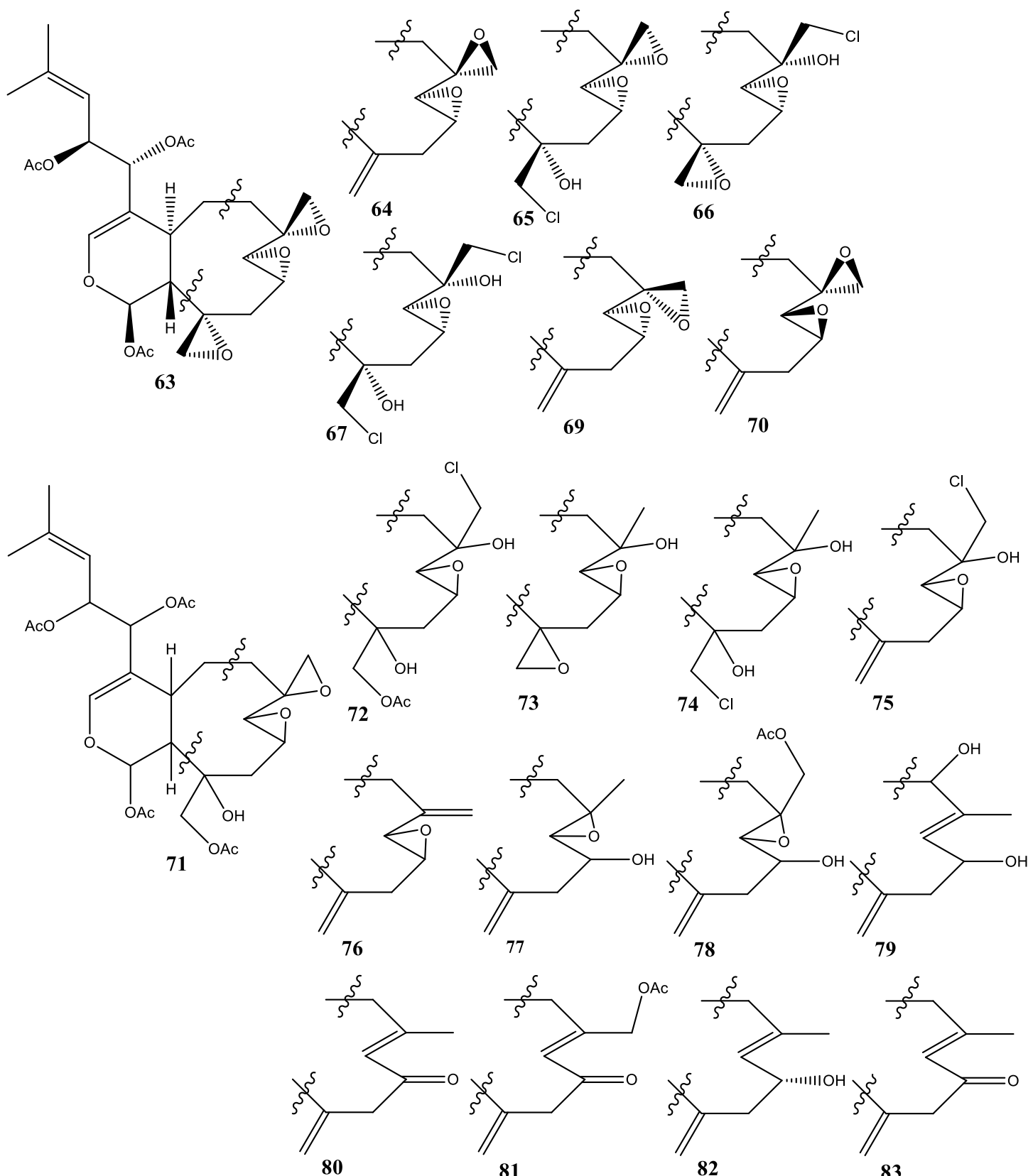

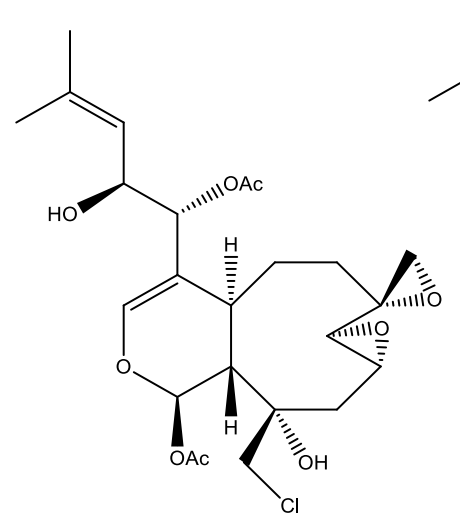

68

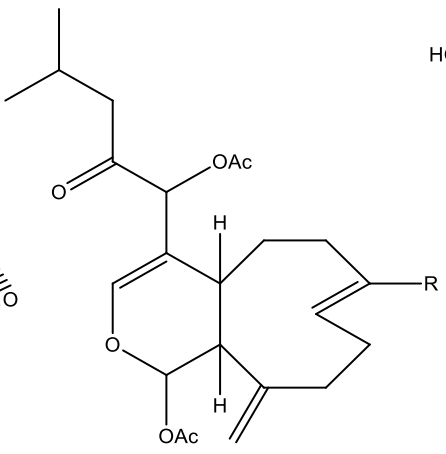

$84 \mathrm{R}=\mathrm{COOH}$

$85 \mathrm{R}=\mathrm{COOMe}$

$86 \mathrm{R}=\mathrm{CHO}$

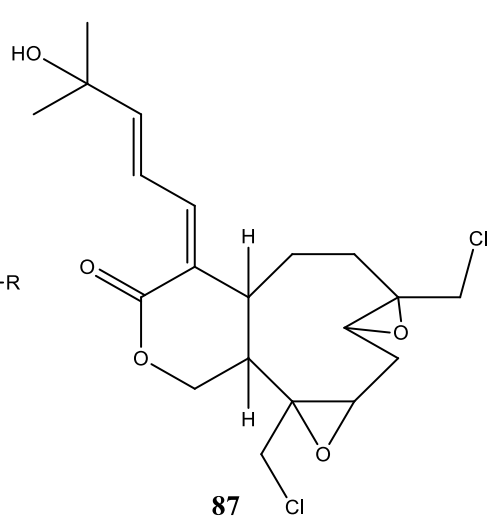

87

Figure 5. Structures of compounds 63-87. 

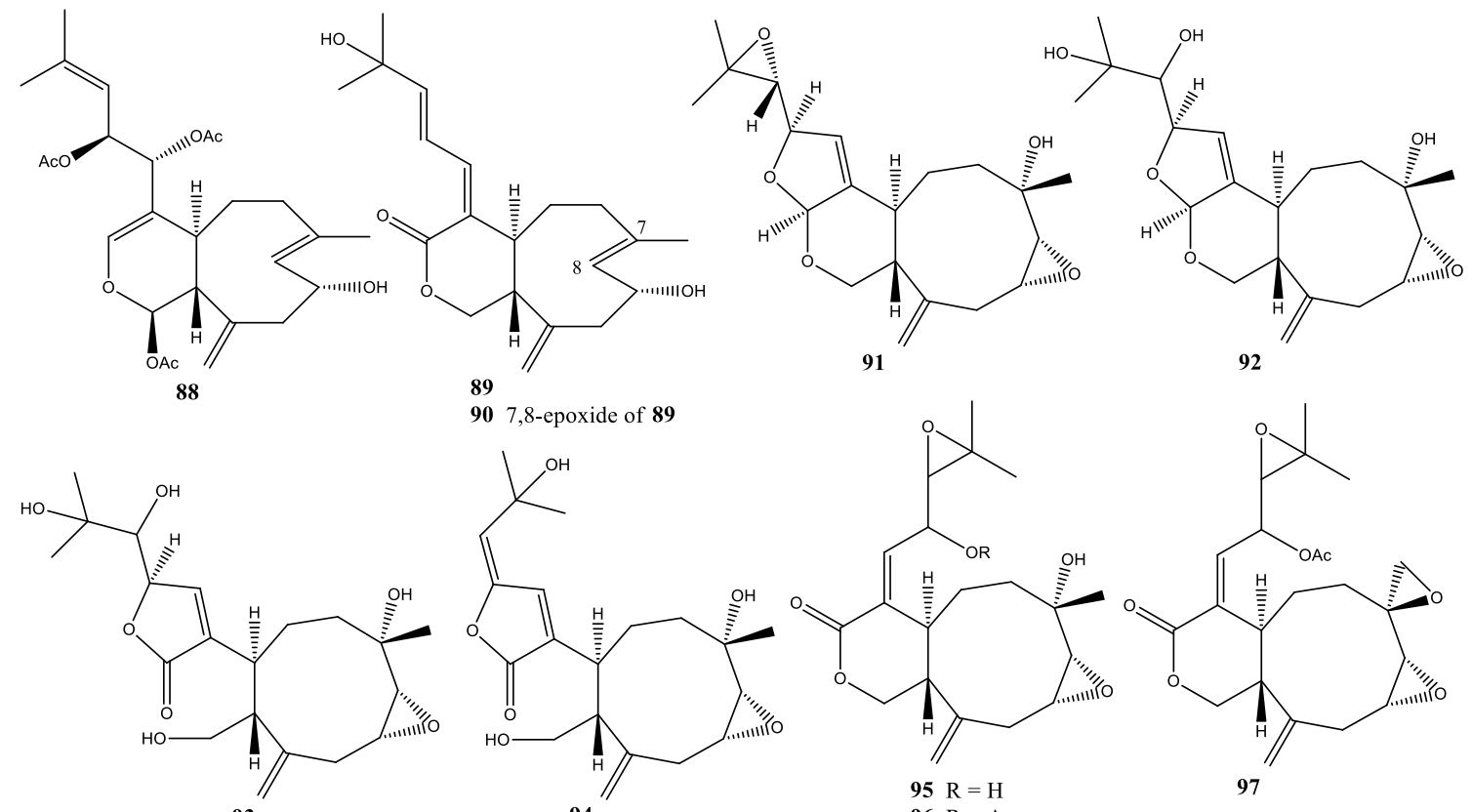

907,8 -epoxide of $\mathbf{8 9}$

91

92

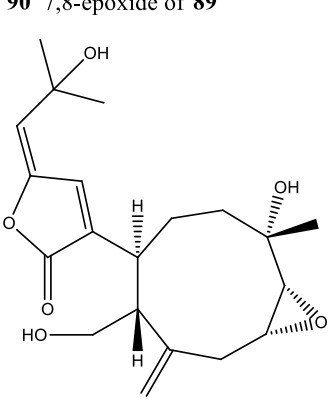

94
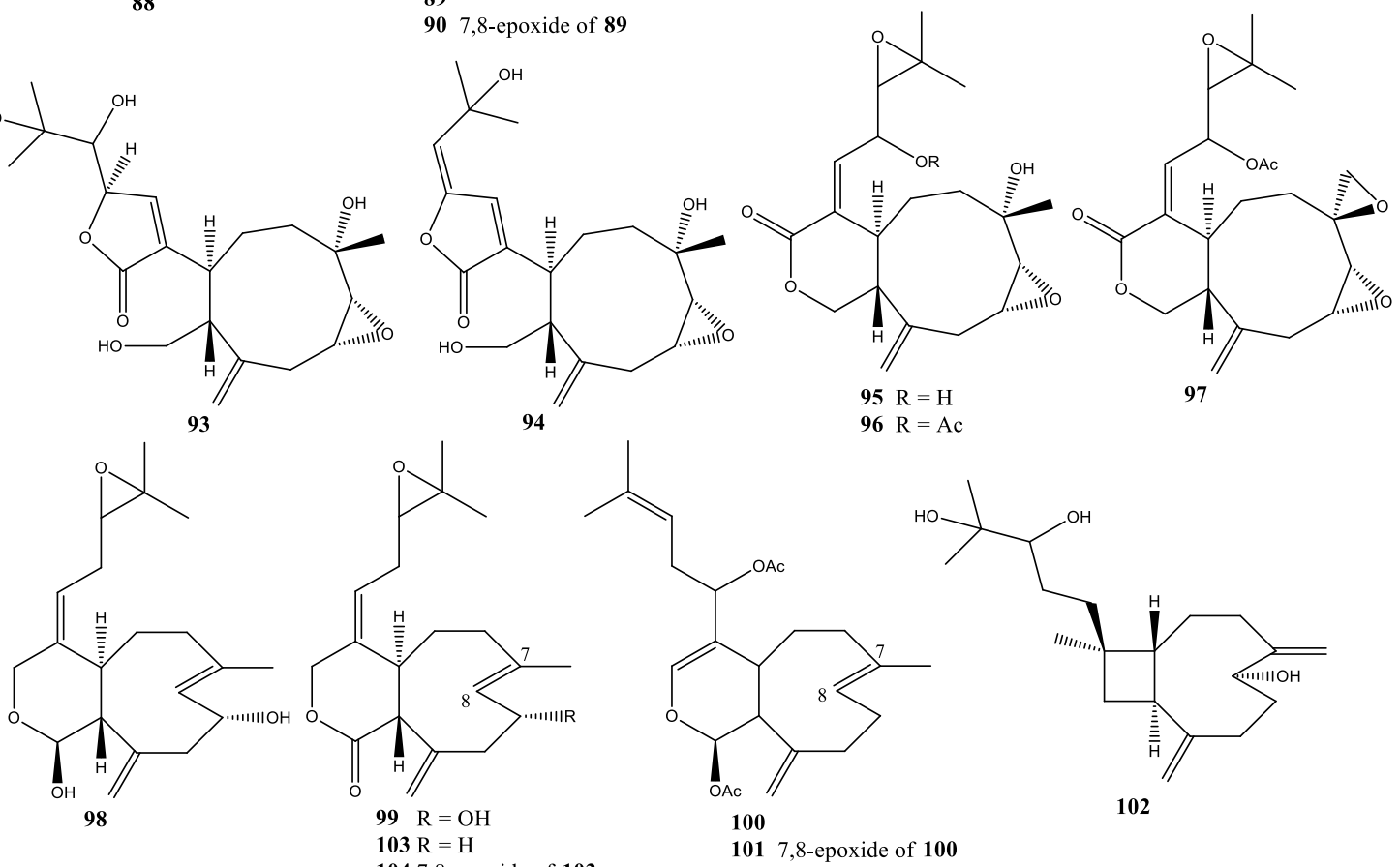

100

101 7,8-epoxide of $\mathbf{1 0 0}$

102

104 7,8-epoxide of 103<smiles>[R]=C1CC[C@H]2/C(=C\C=C\C(C)(C)O)COC(=O)[C@@H]2C(=C)CCC1OO</smiles>

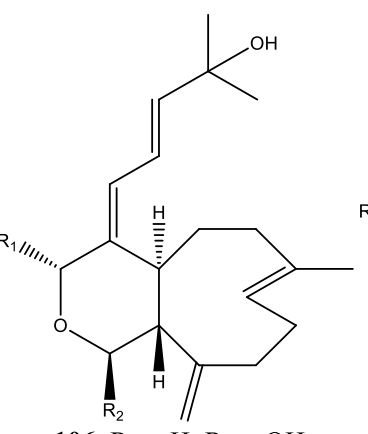

$106 \mathrm{R}_{1}=\mathrm{H} \mathrm{R} \mathrm{R}_{2}=\mathrm{OH}$

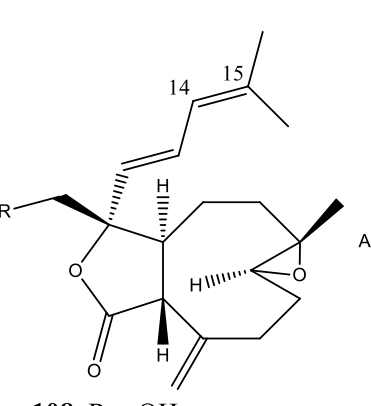

$108 \mathrm{R}=\mathrm{OH}$

$123 \mathrm{R}=\mathrm{OH}$ and 14,15-epoxide $124 \mathrm{R}=\mathrm{OAc}$ and 14,15 -epoxide

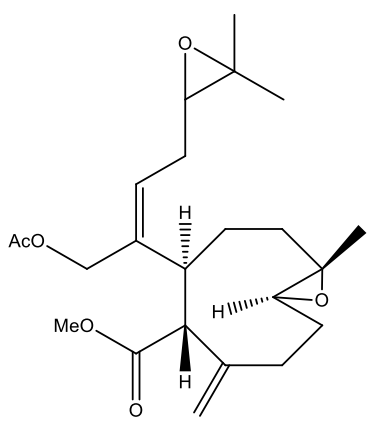

109<smiles>CC(C)(O)/C=C/C=C(/O)[C@@H]1CC[C@]2(C)[C@H](O)C[C@@H]3OC(=O)[C@@]31[C@@H]2O</smiles>
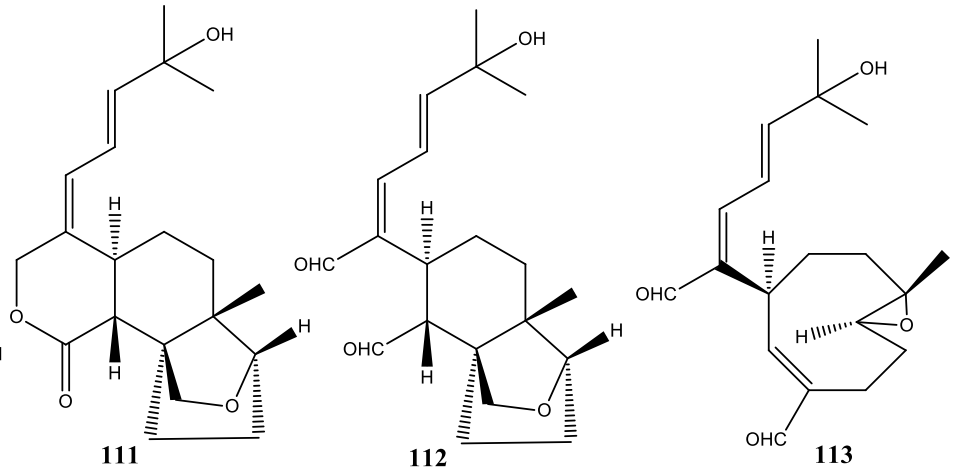

Figure 6. Structures of compounds 88-113 and 123,124. 


\subsection{Xenia Obscuronata}

Two new diterpenoids, xenialactol-D (98) and xeniolide-E (99), were first recorded in both X. obscuronata from the Gulf of Suez, the Red Sea, and X. macrospiculata from Gulf of Eilat, the Red Sea [19]. In the same year, two new diterpenoids, 9-deacetoxy-14,15-deepoxyxeniculin (100) and 9-deacetoxy-14,15-deepoxyxeniculin 7,8-epoxide (101), were isolated from X. obscuronata collected at the Gulf of Suez, the Red Sea [19]. In 1983, one new diterpenoid, xeniaphyllantriol (102), was isolated from X. obscuronata collected at the Gulf of Eilat, the Red Sea [37] (Figure 6).

\subsection{Xenia Umbellata}

In 2002, the X. umbellata, which was collected from Green Island, Taiwan, exhibited seven new diterpenoids: 9-deoxyxeniloide-E (103), 9-deoxy-7,8-epoxyxeniloide-E (104), xeniolide-G (105), 9-deoxyxenialactol-C (106), xenibecin (107), xeniolide-H (108), and xenitacin (109) [45]. In addition, xeniolide-G (105) showed potent cytotoxicity against P-388 (obtained from Department of Medicinal Chemistry and Pharmacognosy, University of Illinois at Chicago) cell line at ED $50.04 \mu \mathrm{g} / \mathrm{mL}$, while xenitacin (109) showed potent cytotoxicity against A-549 (purchased from American Type Culture Collection), HT-29 (purchased from American Type Culture Collection), and P-388 (obtained from Department of Medicinal Chemistry and Pharmacognosy, University of Illinois at Chicago) cell lines at $\mathrm{ED}_{50}$ 3.26, 1.12, and $1.09 \mu \mathrm{g} / \mathrm{mL}$, respectively. In 2005, four new diterpenoids with novel skeleton, namely umbellactal (110), xenibellols A and B (111 and 112), and xenibellal (113), were isolated from X. umbellata (Green Island, off Taiwan) and showed cytotoxicity against P-388 cells with ED 50 3.6, 3.6, 2.8, and 3.2 $\mu \mathrm{g} / \mathrm{mL}$, respectively [24-26], as shown in Figure 6. In 2006, 11 new diterpenoids, namely umbellacins A-I (114-122), 14,15-epoxy-xeniolide H (123), and 3-acetyl-14,15-epoxy-xeniolide $\mathrm{H}$ (124), were isolated from X. umbellata collected at Green Island, off Taiwan [46]. Cytotoxicity of umbellacins B (115), D-F (117-119), and H-I (121,122) against P-388 cells showed ED 50 of 1.6, 4.2, 3.8, 3.7, 3.4, and $3.6 \mu \mathrm{g} / \mathrm{mL}$, respectively. In the following year, two new xeniolides, xenibelatols A and B (125 and 126), were isolated from X. umbellata collected at Green Island, off Taiwan [47]. In 2016, one new diterpenoid, xeniumbellal (127), was isolated from X. umbellata collected at Red Sea Coast, Jeddah, Saudi Arabia [48]. Moreover, xeniumbellal (127) and pentahydroxygorgosterol (201) displayed antibacterial activity against Acinetobacter baumannii with MIC values of 0.22 and $0.28 \mathrm{mM}$, respectively [48] (Figure 7).

\subsection{Xenia Viridis}

In 1979, the first modified tricyclic xenicin (128) was isolated from X. viridis collected at Old Reef, off Townsville, Australia [27]. In 2007, two new xenicins, 16,17-diacetoxy-9,13-deacetoxyxenicin (129) and 16,17-diacetoxy-7,8-oxirene-9,13-deacetoxyxenicin (130), were isolated from X. viridis collected at New Caledonia [49] (Figure 7). 

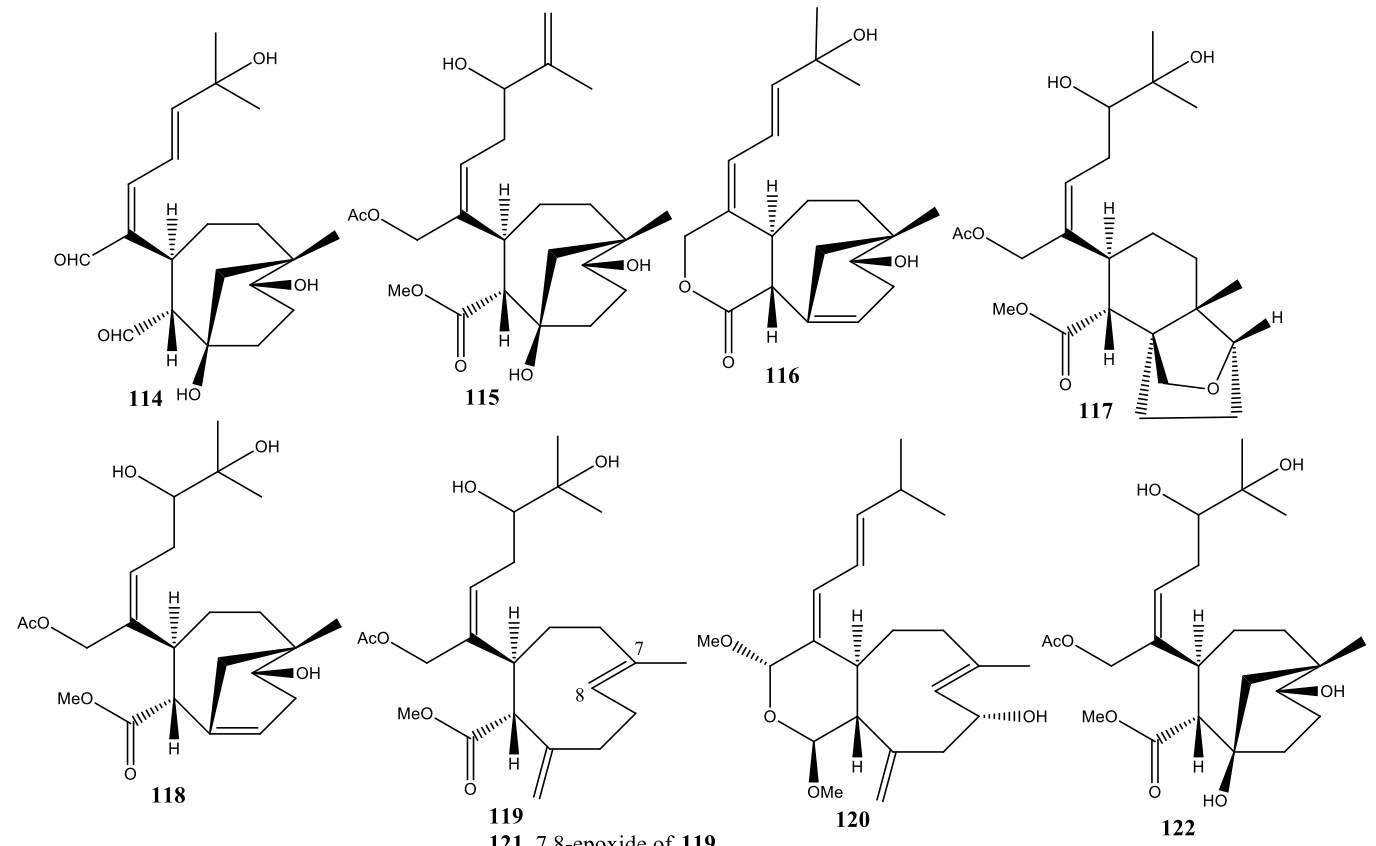

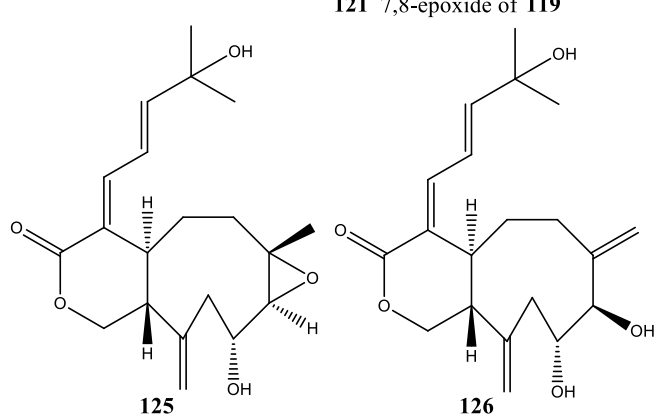

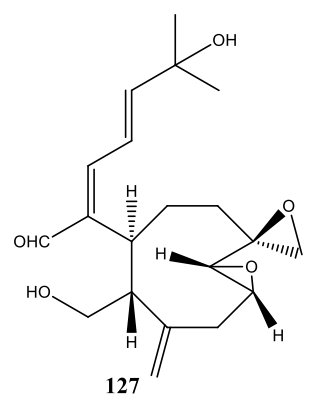

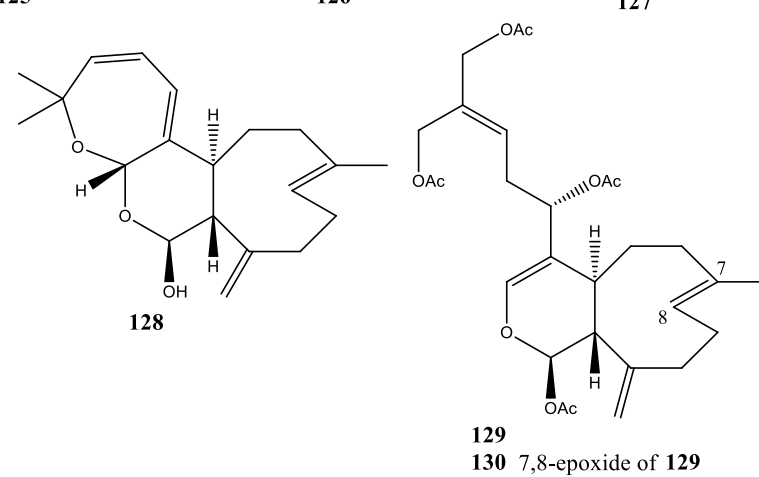

Figure 7. Structures of compounds 114-122 and 125-130.

\subsection{Xenia sp.}

Two pairs of new diastereomeric diterpenes, the first pair being xeniolone (131) and isoxeniolone (132) and the second pair being hydratoxeniolone (133) and hydratoisoxeniolone (134), and a new germacrane-type diterpenoid, germacrexeniolone (135), were isolated from Xenia sp. collected at Zamami-jima, Okinawa Prefecture, Japan [50,51]. This was the first isolation of perhydroazulene skeleton diterpenoids from the soft coral of Xenia sp. In 1995, two new diterpenoids, 9-deoxyxeniolide-A (136) and 9-deoxyxeniolide-B (137), were isolated from Xenia sp., and the 9-deoxyxeniolide-A (136) showed the greatest potency of antibacterial activity [52]. In the same year, six new diterpenoids, namely xeniatine A (138), xeniatine A epoxide (139), isoxeniatines A and B (140 and 141), and xeniaethers A and B (142 and 143), were isolated from Xenia sp. collected at Bonotsu, Kagoshima Prefecture, Japan [21]. These compounds, xeniaethers A and B (142 and 143), represented the first isolation of 
diterpenoids containing a tetrahydrofuran fused to a nine-membered ring from soft coral Xenia sp. In 1996, seven new diterpenoids, namely xeniaethers F-H (144-146), isoxeniatine C (147), azamials A and B (148 and 149), and xenicindial (150), were isolated from soft coral Xenia sp. collected at Sata Cape, Kagoshima Prefecture, Japan [53]. In the same year, the same research group reported 13 new diterpenoids, azamilides A-J (151-160) and xeniaethers C-E (161-163), from Xenia sp. collected at Bonotsu, Kagoshima Prefecture, Japan [22,54]. In addition, azamilides A-J (151-160) were the first example of xenicane-type diterpenoids from the genus Xenia with an open A-ring. In 1999, three new diterpenoids, namely xeniaol (164), xeniadiol (165), and xeniatriol (166), were isolated from Xenia sp. collected at Ishigaki Island, Okinawa, Japan [55]. In 2000, one new diterpenoid, xeniaoxolane (167), was isolated from Xenia sp. collected at Ishigaki Island, Okinawa, Japan [56]. In 2002, two new xeniolides, xeniolide-F (168) and 9-hydroxyxeniolide-F (169), were isolated from Xenia sp. collected at Togian Islands near Sulawesi Island, Indonesia [57]. In 2003, two new diterpenoids, dihydroxeniolide-A (170) and isoxeniatriacetate (171), were isolated from Xenia sp. collected at Ishigaki Island, Okinawa, Japan [58]. In 2008, four new diterpenoids, xenimanadins A-D (172-175), were isolated from Xenia sp. collected at Bunaken Marine Park off Manado, North Sulawesi, Indonesia [59]. In 2015, three new diterpenoids (176-178) without given names were isolated from Xenia sp. collected at Miyako Island, Okinawa, Japan [60]. From 2017 to 2018, two new diterpenoids, 12-epi-9-deacetoxyxenicin (179) and 15-deoxy-isoxeniolide-A (180), were isolated from Xenia sp. collected at Mengalum and Mantanani Islands, Sabah, Malaysia [5,61]. In addition, compound $\mathbf{1 7 9}$ showed cytotoxicity against adult T-cell leukemia S1T cells at IC $50.89 \mu \mathrm{g} / \mathrm{mL}$ (Figure 8) [61].

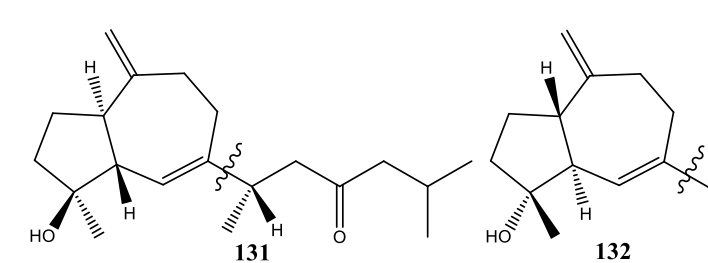

$131-132$

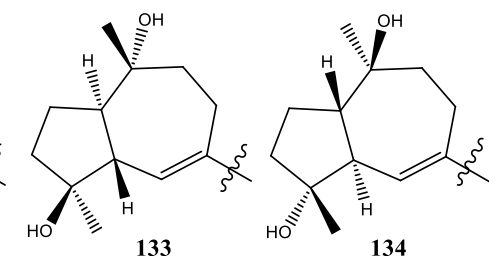

134

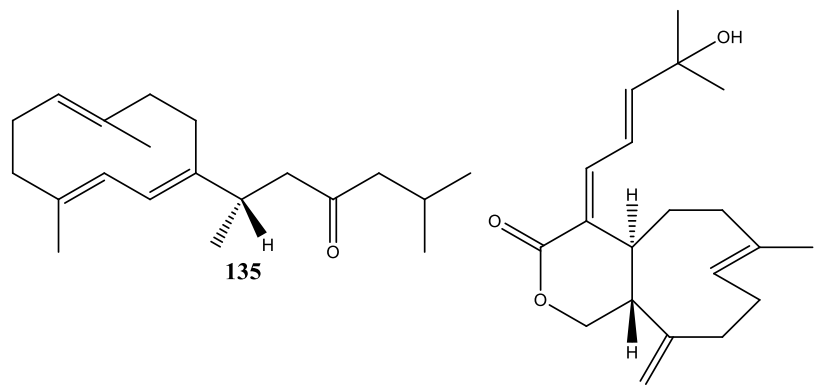

136<smiles>CC1=CCC[C@]2(C)C(=O)OC/C(=C/C=C/C(C)(C)O)[C@]2(C)CC1</smiles>

137

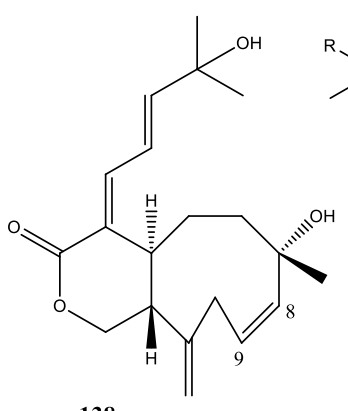

138

$1398,9-\alpha$-epoxide of 138

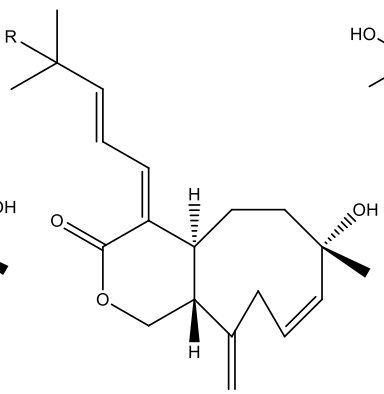

$140 \mathrm{R}=\mathrm{OH}$

$141 \mathrm{R}=\mathrm{H}$

1478,9 - $\alpha$-epoxide of 140

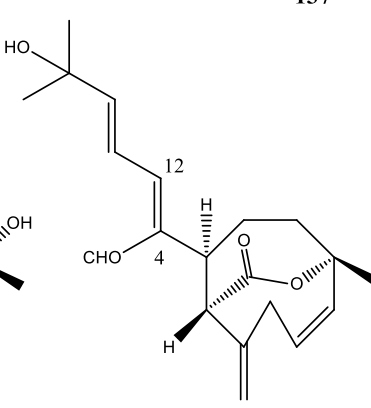

148 $1494,12-E$ of 148

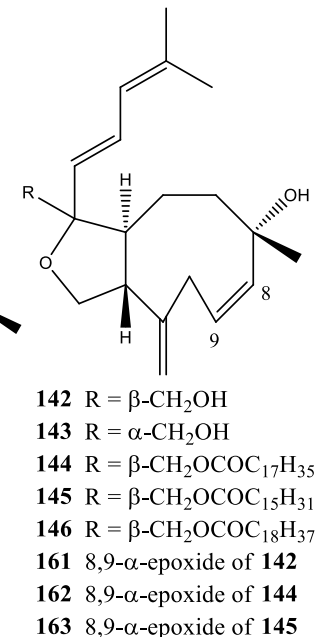

Figure 8. Cont. 


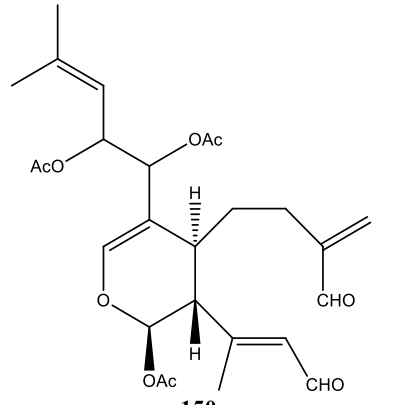<smiles>CC1=CCC[C@]2(C)/C(=C\CC=C(CO)CO)COC(=O)[C@@]2(C)CC1</smiles>

165

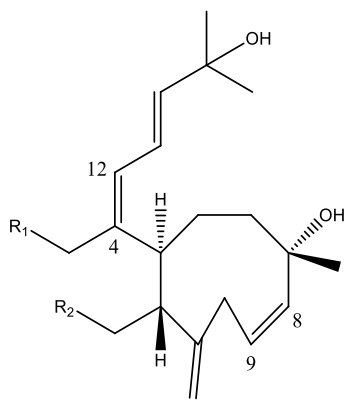

$151 \mathrm{R}_{1}=\mathrm{C}_{17} \mathrm{H}_{35} \mathrm{COO} \mathrm{R}_{2}=\mathrm{OAc}$ $152 \mathrm{R}_{1}=\mathrm{C}_{15} \mathrm{H}_{31} \mathrm{COO} \mathrm{R}_{2}=\mathrm{OAc}$ $153 \mathrm{R}_{1}=\mathrm{C}_{18} \mathrm{H}_{37} \mathrm{COO} \mathrm{R}_{2}=\mathrm{OAc}$ $154 \mathrm{R}_{1}=\mathrm{C}_{19} \mathrm{H}_{39} \mathrm{COO} \mathrm{R}_{2}=\mathrm{OAc}$ $155 \mathrm{R}_{1}=\mathrm{C}_{17} \mathrm{H}_{35} \mathrm{COO} \mathrm{R}_{2}=\mathrm{OH}$ $156 \mathrm{R}_{1}=\mathrm{C}_{15} \mathrm{H}_{31} \mathrm{COO} \mathrm{R}_{2}=\mathrm{OH}$ $1574,12-Z$ of $\mathbf{1 5 2}$

$158 \quad 8,9-\alpha$-epoxide of $\mathbf{1 5 1}$ 159 8,9- $\alpha$-epoxide of $\mathbf{1 5 2}$

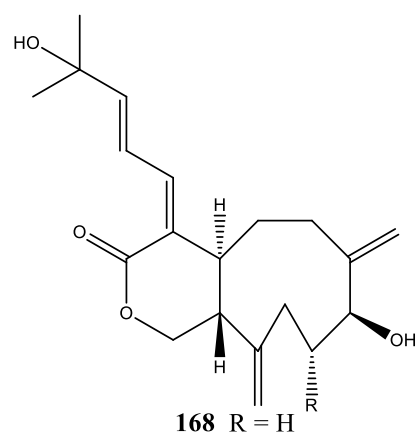
$169 \mathrm{R}=\mathrm{OH}$

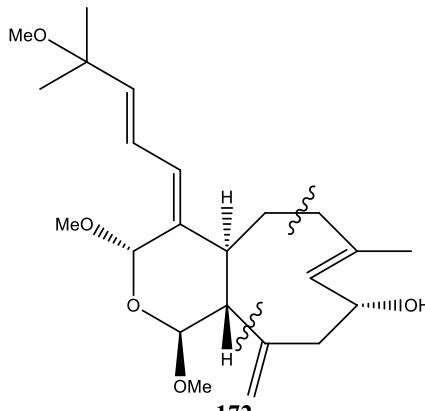

172

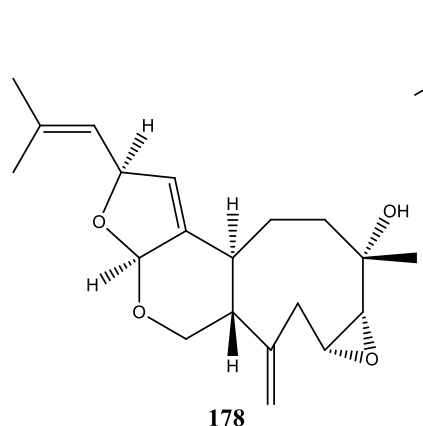
$174 \mathrm{R}=\mathrm{H}$
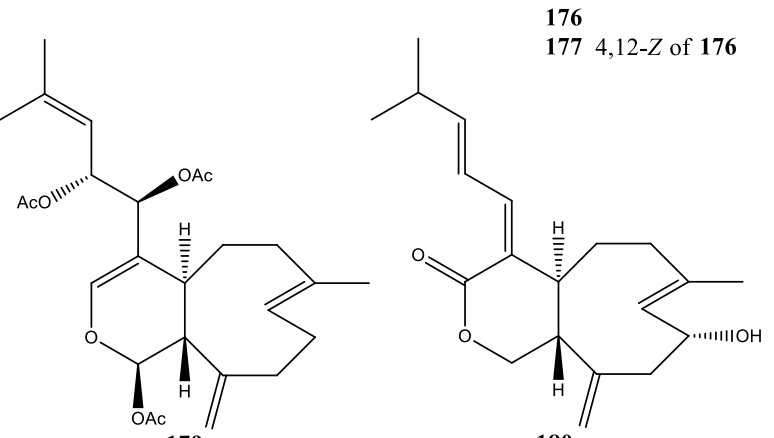

180

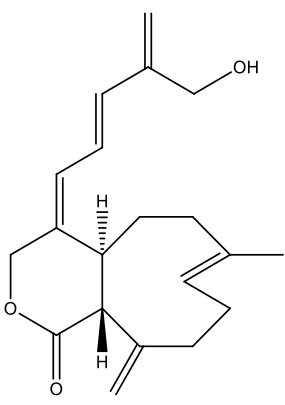

164

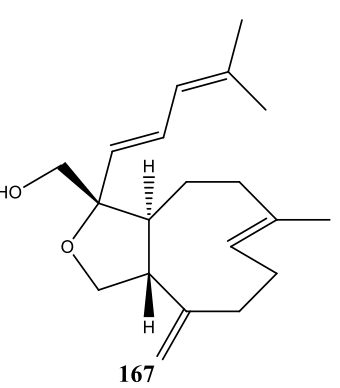

166

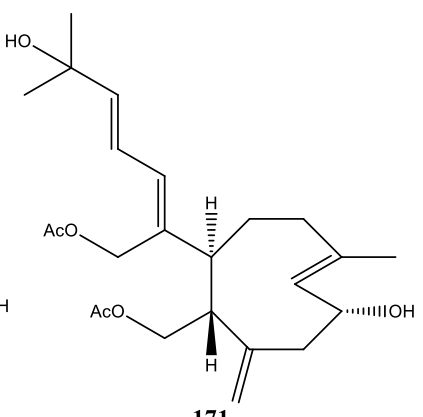

171

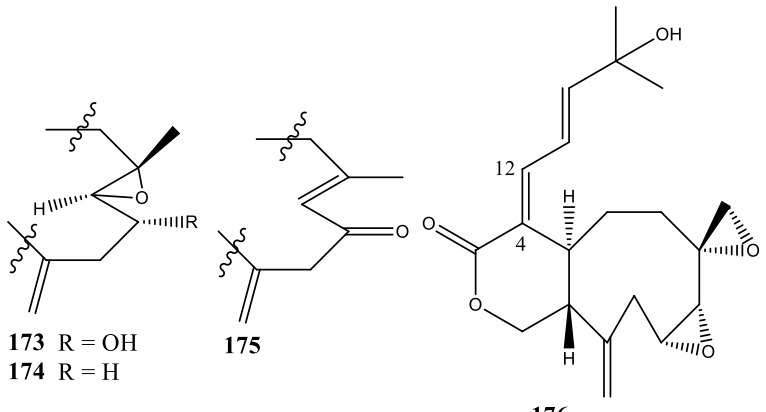

Figure 8. Structures of compounds 131-180. 


\section{Sesquiterpenes}

The first sesquiterpenes isolated from soft coral Xenia were palustrol (181) and 7-acetoxymuurolene (182) from X. obscuronata collected at the Gulf of Eilat, the Red Sea [37]. In 1986, three new sesquiterpenoids, namely 1,2-epoxy-4-isopropyl-1,6-dimethyl-1,2,3,4,4a,7,8,8a-octahydronaphthalene (183), 4-isopropyl-6-methyl-3,4,4a,7,8,8a-hexahydronaphthalene-1-methanol (184), and 5,6-epoxy-4isopropyl-6-methyl-3,4,4a,5,6,7,8,8a-octahydronaphthalene-1-methanol acetate (185), were isolated from two species of Xenia collected at Rib Reef, in the Central Region of the Great Barrier Reef north of Townsville and Hook Reef near the Whitsunday Islands south of Townsville [62]. In 1987, one new sesquiterpenoid, 3,3,7,11-tetramethyltricyclo[6.3.0.0]undec-1(8)-en-4-ol (186), isolated from X. novae-britanniae, was collected at Rib Reef, Townsville, Australia [63]. In 2002, six new cadinenes, xenitorins A-F (187-192), were isolated from X. puerto-galerae collected at Green Island, off Taiwan [64]. In 2007, three new cadinenes, namely 8-epi-xenitorin A (193), 10-epi-xenitorin C (194), and 7-isopropenyl-4,10-dimethyl-2,3,4,5-tetrahydronaphthalene (195), were isolated from X. puerto-galerae collected at Green Island, off Taiwan [65]. In 2018, one new sesquiterpenoid, 10ß-Omethyl- $1 \alpha \mathrm{H}, 5 \alpha \mathrm{H}$-guaia-6-en-4 $\beta$-ol (196), was isolated from X. stellifera collected at Mengalum Island, Sabah, Malaysia [6] (Figure 9).

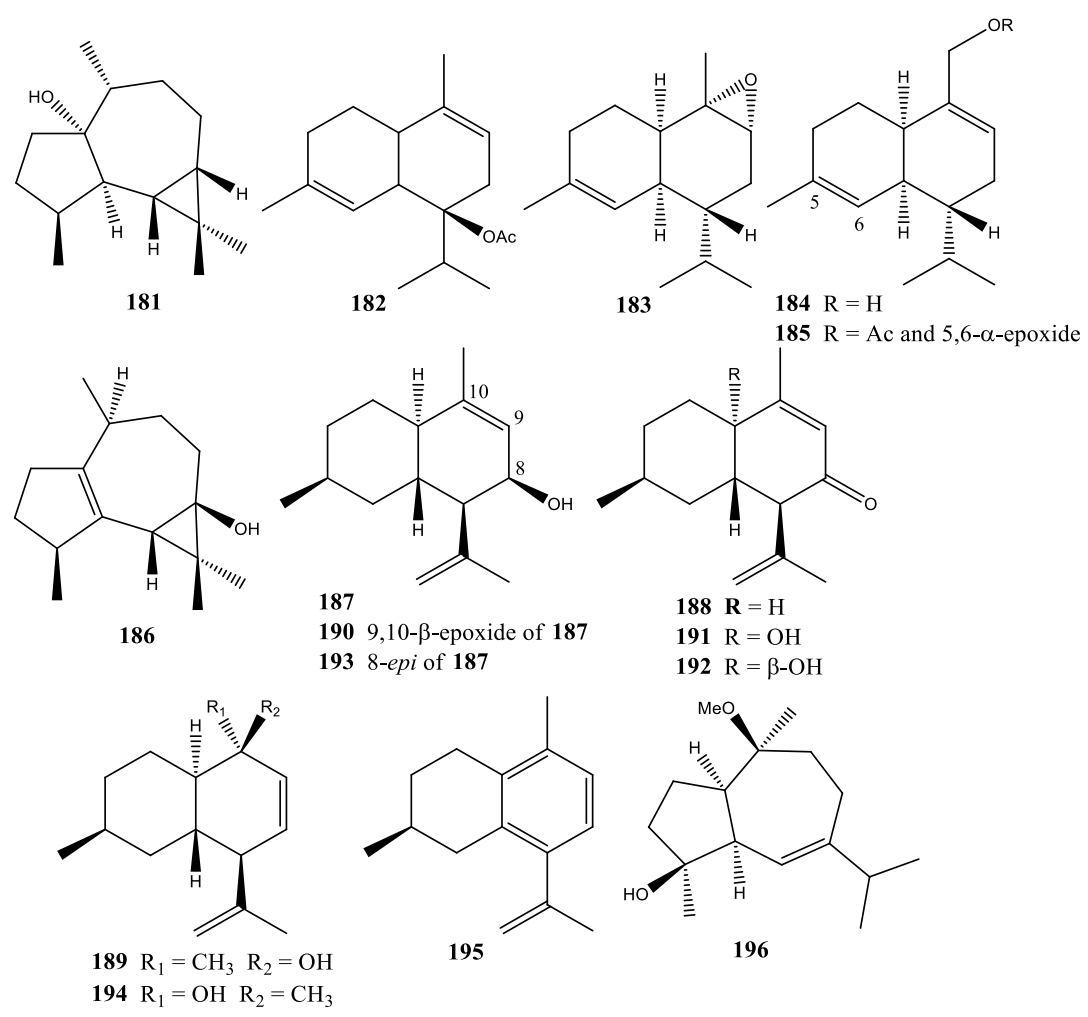

Figure 9. Structures of compounds 181-196.

\section{Steroids}

In 1986, four new steroids, xeniasterols a-d (197-200), were isolated from Xenia sp. collected at Zamami-jima, Okinawa Prefecture, Japan [66]. Moreover, steroids 197-200 showed growth inhibitory activity against B-16 melanoma cells at $\mathrm{IC}_{50} 5 \mu \mathrm{g} / \mathrm{mL}$. In 2016, one new steroid, pentahydroygorgosterol (201), was isolated from X. umbellata collected at Red Sea Coast, Jeddah, Saudi Arabia [48] (Figure 10). 


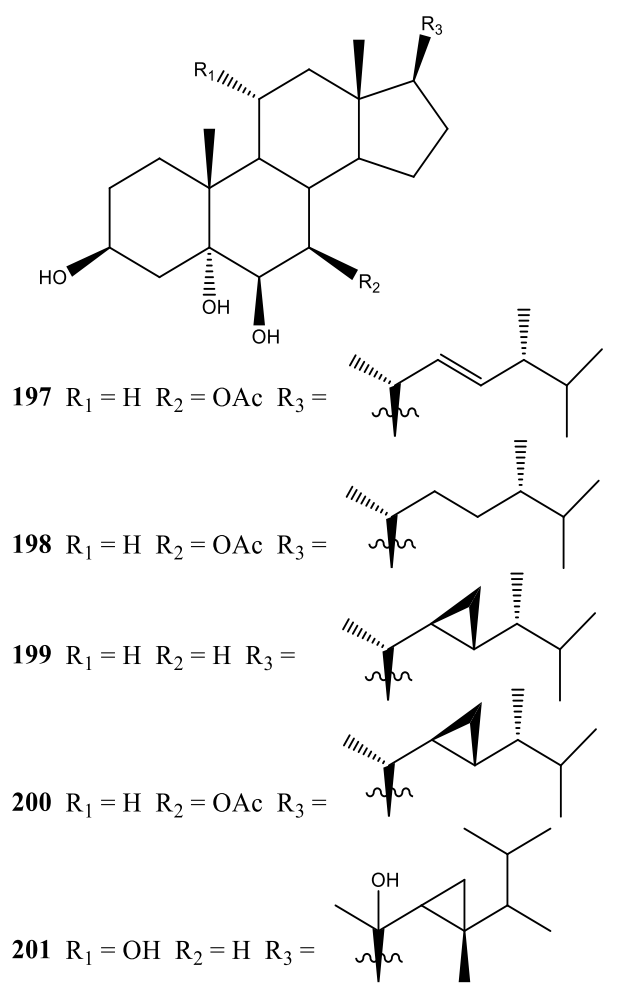

Figure 10. Structures of compounds 197-201.

\section{Synthesis of Xenia Diterpenoids}

As reviewed in the earlier part of this paper, Xenia is well known as a rich source of bioactive compounds, especially possessing anticancer activity. The promising anticancer and antimicrobial activities of the isolated compounds from Xenia as lead pharmaceuticals have attracted the interest of synthetic chemists. However, synthesis of the diterpenoids is challenging, especially when they consist of an E-configuration on the nine-membered rings. Various synthetic approaches have been proposed for a few total syntheses of xeniolides. Ring expansion, ring-closing, and ring-contracting reactions are among the approaches depending on the individual substitution pattern of the target compound [67]. As for reports on the synthesis of such diterpenoids, there is an apparent lack of data due to the challenge of synthesizing nine-membered rings. To date, there is no reported total synthesis of xenicins, and only a few total syntheses of xeniolides have been accomplished [67].

\section{Conclusions}

This paper presents a review of the terpenes discovered in the soft coral Xenia and their biological activities. From 1977 to 2018, a total of 199 terpenes, including 14 sesquiterpenes, 180 diterpenes and 5 steroids, were found in soft coral Xenia for the first time. These species of soft coral Xenia, including X. blumi, X. crassa, X. elongata, X. faraunensis, X. florida, X. lilielae, X. macrospiculata, X. membranacea, X. novae-britanniae, X. obscuronata, X. puerto-galerae, X. stellifera, X. umbellata, X. viridis, and Xenia sp., were primarily collected at Green Island in Taiwan, regions of Kagoshima and Okinawa in Japan, Gulf of Eilat at the Red Sea, Townsville in Australia, and Sarcelle Pass south of New Caledonia. The assessment of cytotoxicity against cancer cell lines is the most frequent biological evaluation reported for these terpenes, and most of them were not widely tested for their biological potential. An investigation of the diversity in soft coral family Xeniidae revealed that Xenia was polyphyletic [68]. This suggested that it might not be suitable to place soft coral belonging to the genus Xenia in a single taxon as their morphological characteristics used for traditional taxonomy are not well reflected in the phylogeny in this genus [68]. A recent study from Maloney and McFadden's group suggested that chemical studies in the last 50 years on soft coral Sarcophyton may have unknowingly comprised different cryptic 
species of Sarcophyton glaucum, leading to apparently distinctive chemical variation [69]. In the future, such studies should be carried out for soft coral Xenia to gain more understanding of their idiosyncratic chemical variation. In the course of this review, we realized that most of the early reports of natural products chemistry of this genus did not place much importance on the proper authentication of the collected specimens. Most did not report voucher specimen numbers or deposits at biodiversity collection centers. This is quite understandable, but with the Nagoya Protocol coming into force in 2014, these are important matters that a natural products chemist can no longer avoid. Therefore, because the collected marine invertebrate specimens always exhibit a high degree of morphological plasticity and differences due to geographical locations, their proper identification and voucher specimen deposition is warranted for future reference. In addition, recent advancement of technology, particularly in DNA sequencing, has provided sufficient molecular information to facilitate soft coral identification in a more precise and swift manner. The authors recommend the inclusion of morphological and molecular information in articles in future studies. It is also important to realize that compounds isolated from these invertebrates are important not only for their biological potential, but also as a vital tool for chemo-taxonomical studies.

Author Contributions: Conceptualization, T.I. and T.H.; resources, T.K.; writing-original draft preparation, C.-S.P.; writing - review and editing, S.-Y.N.; editing of draft and supervision, C.S.V.; funding acquisition, T.K. and C.S.V. All authors have read and agreed to the published version of the manuscript.

Funding: This research received no external funding.

Acknowledgments: The authors acknowledge the University of the Ryukyus and Shizuoka Institute of Science and Technology for the SciFinder facility.

Conflicts of Interest: The authors declare no conflict of interest.

\section{References}

1. Ahmed, A.F.; Chen, Y.W.; Huang, C.Y.; Tseng, Y.J.; Lin, C.C.; Dai, C.F.; Wu, Y.C.; Shen, J.H. Isolation and structure elucidation of cembranoids from a Dongsha Atoll soft coral Sacrophyton stellatum. Mar. Drugs 2018, 16, 210. [CrossRef]

2. Huang, C.Y.; Tseng, W.R.; Ahmed, A.F.; Chiang, P.L.; Tai, C.L.; Hwang, T.L.; Dai, C.F.; Sheu, J.H. Anti-inflammatory polyoxygenated steroids from the soft coral Lobophytum michaelae. Mar. Drugs 2018, 16, 93. [CrossRef] [PubMed]

3. Li, S.W.; Chen, W.T.; Yao, L.G.; Guo, Y.W. Two new cytotoxic steroids from the Chinese soft coral Sinularia sp. Steroids 2018, 136, 17-21. [CrossRef] [PubMed]

4. $\quad$ Liang, L.F.; Kurtán, T.; Mándi, A.; Yao, L.G.; Li, J.; Lan, L.F.; Guo, Y.W. Structural, stereochemical, and bioactive studies of cembranoids from Chinese soft coral Sarcophyton trocheliophorum. Tetrahedron 2018, 74, 1933-1941. [CrossRef]

5. Phan, C.S.; Kamada, T.; Kobayashi, K.; Hamada, T.; Vairappan, C.S. 15-Deoxy-isoxeniolide-A, new diterpenoid from a Bornean soft coral, Xenia sp. Nat. Prod. Res. 2018, 32, 202-207. [CrossRef] [PubMed]

6. Phan, C.S.; Kamada, T.; Ishii, T.; Hamada, T.; Vairappan, C.S. A new guaiane-type sesquiterpenoid from a Bornean soft coral, Xenia stellifera. Nat. Prod. Commun. 2018, 13, 15-16. [CrossRef]

7. Wu, C.H.; Chai, C.H.; Huang, T.Z.; Huang, C.Y.; Hang, T.L.; Dai, C.F.; Sheu, J.H. Cembranoid-related metabolites and biological activities from the soft coral Sinularia flexibilis. Mar. Drugs 2018, 16, 278. [CrossRef]

8. Ye, F.; Li, J.; Wu, Y.; Zhu, Z.D.; Mollo, E.; Gavagnin, M.; Gu, Y.C.; Zhu, W.L.; Li, X.W.; Guo, Y.W. Sarinfacetamides A and B, nitrogenous diterpenoids with tricycle[6.3.1.0 1,5]dodecane scaffold from the South China Sea soft coral Sarcophyton infundibuliforme. Org. Lett. 2018, 20, 2637-2640. [CrossRef]

9. Green, D.; Carmely, S.; Benayahu, Y.; Kashman, Y. Antheliolide A \& B: Two new $\mathrm{C}_{24}$-acetoacetylated diterpenoids of the soft coral Anthelia glauca. Tetrahedron 1988, 29, 1605-1608.

10. Lin, Y.S.; Fazary, A.E.; Chen, C.H.; Kuo, Y.H.; Shen, Y.C. Bioactive xenicane diterpenoids from the Taiwanese soft coral Asterospicularia laurae. Chem. Biodivers. 2011, 8, 1310-1317. [CrossRef]

11. Hooper, G.J.; Davies-Coleman, M.T. New metabolites from the south African soft coral Capnella thyrsoidea. Tetrahedron 1995, 51, 9973-9984. [CrossRef] 
12. Hooper, G.J.; Davies-Coleman, M.T.; Schleyer, M. New diterpenes from the South African soft coral Eleutherobia aurea. J. Nat. Prod. 1997, 60, 889-893. [CrossRef] [PubMed]

13. Tanaka, J.; Ogawa, N.; Liang, J.; Higa, T. Helioxenicins A-C: Diterpenes from the blue coral Heliopora coerulea. Tetrahedron 1994, 50, 9989-9996. [CrossRef]

14. Chen, S.P.; Su, J.H.; Ahmed, A.F.; Dai, C.F.; Wu, Y.C.; Sheu, J.H. Xeniaphyllane-derived terpenoids from the Formosan soft coral Sinularia gibberosa. Chem. Pharm. Bull. 2007, 55, 1471-1475. [CrossRef]

15. Schwartz, R.E.; Scheuer, P.J.; Zabel, V.; Watson, W.H. The coraxeniolides, constituents of pink coral, corallium sp. Tetrahedron 1981, 37, 2725-2733. [CrossRef]

16. Fusetani, N.; Asano, M.; Matsunaga, S.; Hashimoto, K. Acalycixeniolides, novel norditerpenes with allene functionality from two gorgornians of the genus Acalycigorgia. Tetrahedron 1989, 45, 1647-1652. [CrossRef]

17. Vanderah, D.J.; Steudler, P.A.; Ciereszko, L.S.; Schmitz, F.J.; Ekstrand, J.D.; van der Helm, D. Marine natural products. Xenicin: A diterpenoid possessing a nice-membered ring from the soft coral, Xenia elongata. J. Am. Chem. Soc. 1977, 99, 5780-5784. [CrossRef]

18. Kashman, Y.; Groweiss, A. Xeniolide-A and xeniolide-B, two new diterpenoids from the soft-coral Xenia macrospiculata. Tetrahedron Lett. 1978, 19, 4833-4836. [CrossRef]

19. Kashman, Y.; Groweiss, A. New diterpenoids from the soft corals Xenia macrospiculata and Xenia obscuronata. J. Org. Chem. 1980, 45, 3824-3827. [CrossRef]

20. Iwagawa, T.; Kawasaki, J.; Hase, T.; Yu, C.M.; Walter, J.A.; Wright, J.L.C. A new tricarbocyclic diterpene structure from the soft coral Xenia florida. J. Chem. Soc. Chem. Commun. 1994, 18, 2073-2074. [CrossRef]

21. Iwagawa, T.; Amano, Y.; Hase, T.; Shiro, M. New xenia diterpenoids from a soft coral, xenia species 1. Tetrahedron 1995, 51, 11111-11118. [CrossRef]

22. Iwagawa, T.; Amano, Y.; Nakatani, M.; Hase, T. New xenia diterpenoids from a soft coral, Xenia species containing fatty acyl side chains. Bull. Chem. Soc. Jpn. 1996, 69, 1309-1312. [CrossRef]

23. El-Gamal, A.A.H.; Chiang, C.Y.; Huang, S.H.; Wang, S.K.; Duh, C.Y. Xenia diterpenoids from the Formosan soft coral Xenia blumi. J. Nat. Prod. 2005, 68, 1336-1340. [CrossRef] [PubMed]

24. El-Gamal, A.A.H.; Wang, S.K.; Duh, C.Y. Umbellactal, a novel diterpenoid from the Formosan soft coral Xenia umbellata. Tetrahedron Lett. 2005, 46, 6095-6096. [CrossRef]

25. El-Gamal, A.A.H.; Wang, S.K.; Duh, C.Y. Xenibellols A and B, new diterpenoids from the Formosan soft coral Xenia umbellata. Org. Lett. 2005, 7, 2023-2025. [CrossRef]

26. El-Gamal, A.A.H.; Wang, S.K.; Duh, C.Y. Xenibellal, a novel norditerpenoid from the Formosan soft coral Xenia umbellata. Tetrahedron Lett. 2005, 46, 4499-4500. [CrossRef]

27. Bowden, B.F.; Coll, J.C.; Ditzel, E.; Mitchell, S.J.; Robinson, W.T. Studies of Australian soft corals. XXVIII. The structure determination of two new diterpenes from the genus Xenia (Alcyonacea). Aust. J. Chem. 1982, 35, 997-1002. [CrossRef]

28. Miyamoto, T.; Takenaka, Y.; Yamada, K.; Higuchi, R. Bioactive diterpenoids from Octocorallia, deoxyxeniolide B, a novel ichthyotoxic diterpenoid from the soft coral Xenia elongata. J. Nat. Prod. 1995, 58, 924-928. [CrossRef]

29. Andrianasolo, E.H.; Haramaty, L.; Degenhardt, K.; Mathew, R.; White, E.; Lutz, R.; Falkowski, P. Induction of apoptosis by diterpenes from the soft coral Xenia elongata. J. Nat. Prod. 2007, 70, 1551-1557. [CrossRef]

30. Andrianasolo, E.H.; Haramaty, L.; White, E.; Lutz, R.; Falkowski, P. Mode of action of diterpene and characterization of related metabolites from the soft coral, Xenia elongata. Mar. Drugs 2014, 12, 1102-1115. [CrossRef]

31. Kashman, Y.; Saltoun, M.; Rudi, A.; Benayahu, Y. Xeniafaraunol A and B, and faraunatin; three new cytotoxic diterpenes from the soft coral Xenia faraunensis. Tetrahedron Lett. 1994, 35, 8855-8858. [CrossRef]

32. Iwagawa, T.; Kawasaki, J.; Hase, T.; Wright, J.L.C. New di- and tricarbocyclic diterpenes possessing a bicyclic [4.3.1] ring system isolated from the soft coral, Xenia florida. Tetrahedron 1997, 53, 6809-6816. [CrossRef]

33. Iwagawa, T.; Kawasaki, J.; Hase, T. New xenia diterpenoids isolated from the soft coral, Xenia florida. J. Nat. Prod. 1998, 61, 1513-1515. [CrossRef] [PubMed]

34. Iwagawa, T.; Nakamura, K.; Hirose, T.; Okamura, H.; Nakatani, M. New xenicane diterpenes isolated from the acetone extract of the soft coral Xenia florida. J. Nat. Prod. 2000, 63, 468-472. [CrossRef] [PubMed]

35. Shen, Y.C.; Lin, Y.C.; Ahmed, A.F.; Kuo, Y.H. New xenicane diterpenoids from Xenia florida. Tetrahedron Lett. 2005, 46, 4793-4796. [CrossRef]

36. Cheng, Y.B.; Jang, J.Y.; Khalil, A.T.; Kuo, Y.H.; Shen, Y.C. Xenicane-type diterpenes with cytotoxicity from Xenia florida. J. Nat. Prod. 2006, 69, 675-678. [CrossRef] [PubMed] 
37. Groweiss, A.; Kashman, Y. Eight new xenia diterpenoids from three soft corals of the Red Sea. Tetrahedron 1983, 39, 3385-3396. [CrossRef]

38. Groweiss, A.; Kashman, Y. Xeniculin, xeniaphyllenol and xeniaphyllenol oxide, new diterpenoids from the soft-coral Xenia macrospiculata. Tetrahedron Lett. 1978, 19, 2205-2208. [CrossRef]

39. Lelong, H.; Ahond, A.; Chiaroni, A.; Poupat, C.; Riche, C.; Potier, P.; Pusset, J.; Pusset, M.; Laboute, P.; Menou, J.L. Invertébrés marins du lagon Néo-Calédonien, VIII. Métabolites terpéniques de Xenia membranacea. J. Nat. Prod. 1987, 50, 203-210. [CrossRef]

40. Almourabit, A.; Ahond, A.; Chiaroni, A.; Poupat, C.; Riche, C.; Potier, P.; Laboute, P.; Menou, J.L. Invertébrés marins du lagon Néo-Calédonien, IX. Havannachlorhydrines, nouveaux métabolites de Xenia membranacea: Étude structural et configuration absolue. J. Nat. Prod. 1988, 51, 282-292. [CrossRef]

41. Almourabit, A.; Gillet, B.; Ahond, A.; Beloeil, J.C.; Poupat, C.; Potier, P. Invertébrés marins du lagon Néo-Calédonien, XI. Les desoxyhavannahines, nouveaux métabolites de Xenia membranacea. J. Nat. Prod. 1989, 52, 1080-1087. [CrossRef]

42. Almourabit, A.; Ahond, A.; Poupat, C.; Potier, P. Invertébrés marins du lagon Néo-Calédonien, XII. Isolement et étude structural de nouveaux diterpénes extraits de l'alcyonaire Xenia membranacea. J. Nat. Prod. 1990, 53, 894-908. [CrossRef]

43. Braekman, J.C.; Daloze, D.; Tursch, B.; Declercq, J.P.; Germain, G.; van Meerssche, M. Chemical studies of marine invertebrates. XXXIX. Three novel diterpenoids from the soft coral Xenia novae-britanniae. Bull. Soc. Chem. Belg. 1979, 88, 71-77. [CrossRef]

44. Bishara, A.; Rudi, A.; Goldberg, I.; Benayahu, Y.; Kashman, Y. Novaxenicins A-D and xeniolides I-K, seven new diterpenes from the soft coral Xenia novaebrittanniae. Tetrahedron 2006, 62, 12092-12097. [CrossRef]

45. Duh, C.Y.; El-Gamal, A.A.H.; Chiang, C.Y.; Chu, C.J.; Wang, S.K.; Dai, C.F. New cytotoxic xenia diterpenoids from the Formosan soft coral Xenia umbellata. J. Nat. Prod. 2002, 65, 1882-1885. [CrossRef]

46. El-Gamal, A.A.H.; Wang, S.K.; Duh, C.Y. Cytotoxic xenia diterpenoids from the soft coral Xenia umbellata. J. Nat. Prod. 2006, 69, 338-341. [CrossRef] [PubMed]

47. Shen, Y.C.; Chen, Y.H.; Cheng, Y.B.; Kuo, Y.H.; Khalil, A.T. Two new xeniolides from a Taiwanese Xenia soft coral. Nat. Prod. Res. 2007, 21, 1171-1177. [CrossRef]

48. Ayyad, S.E.N.; Alarif, W.M.; Al-Footy, K.O.; Selim, E.A.; Ghandourah, M.A.; Aly, M.M.; Alorfi, H.S. Isolation, antimicrobial and antitumor activities of a new polyhydroxysteroid and a new diterpenoid from the soft coral Xenia umbellata. Z. Nat. 2016, 72, 27-34. [CrossRef]

49. Janairo, J.R.; Janairo, G.C.; Ragasa, C.Y.; Bowden, B.F. New xenicanes from Xenia viridis. Nat. Prod. Res. 2007, 21, 1067-1072. [CrossRef]

50. Kobayashi, M.; Zheng, C.; Yang, C.; Kyogoku, Y.; Kitagawa, I. Xeniolone and isoxeniolone two new diterpenes having a perhydroazulene skeleton from an Okinawan soft coral of Xenia sp. Chem. Pharm. Bull. 1985, 34, 4641-4652. [CrossRef]

51. Kitagawa, I.; Zheng, C.; Yang, C.; Kobayashi, M.; Kyogoku, Y. Marine natural products. XVI. Structures of five new diterpenes from an Okinawan soft coral of Xenia sp. (Xeniidae). Chem. Pharm. Bull. 1986, 34, 4641-4652. [CrossRef]

52. Vervoort, H.C.; Fenical, W. Antibacterial diterpenoids from an undescribed soft-coral of the genus Xenia. Nat. Prod. Lett. 1995, 6, 49-55. [CrossRef]

53. Iwagawa, T.; Masuda, T.; Okamura, H.; Nakatani, M. New xenia diterpenoids from a Xenia species of a soft coral. Tetrahedron 1996, 52, 13121-13128. [CrossRef]

54. Iwagawa, T.; Amano, Y.; Okamura, H.; Nakatani, M.; Hase, T. New xenia diterpenoids from a soft coral Xenia species. Heterocycles 1996, 43, 1271-1277. [CrossRef]

55. Miyaoka, H.; Nakano, M.; Iguchi, K.; Yamada, Y. Three new xenicane diterpenoids from Okinawan soft coral of the genus Xenia. Tetrahedron 1999, 55, 12977-12982. [CrossRef]

56. Miyaoka, H.; Mitome, H.; Nakano, M.; Yamada, Y. Xeniaoxolane: A new xenicane-type diterpenoid from the Okinawan soft coral, Xenia sp.; absolute configurations of xeniaoxolane, xeniolide-A and xenialactol. Tetrahedron 2000, 25, 7737-7740. [CrossRef]

57. Anta, C.; González, N.; Santafé, G.; Rodríguez, J.; Jiménez, C. New xenia diterpenoids from the Indonesian soft coral Xenia sp. J. Nat. Prod. 2002, 65, 766-768. [CrossRef]

58. Miyaoka, H.; Nakano, M.; Iguchi, K.; Yamada, Y. Two new xenicane diterpenoids from Okinawan soft coral of the genus Xenia. Heterocycles 2003, 61, 189-196. [CrossRef] 
59. Fattorusso, E.; Romano, A.; Taglialatela-Scafati, O.; Achmad, M.J.; Bavestrello, G.; Cerrano, C. Xenimanadins A-D, a family of xenicane diterpenoids from the Indonesian soft coral Xenia sp. Tetrahedron 2008, 64, 3141-3146. [CrossRef]

60. Maarisit, W.; Yano, K.; Miyazato, T.; Roy, P.K.; Taira, J.; Ueda, K. Structures and bioactivities of xenicanes from an Okinawan soft coral Xenia sp. Heterocycles 2015, 91, 505-514.

61. Phan, C.S.; Kamada, T.; Ishii, T.; Hamada, T.; Vairappan, C.S. 12-Epi-9-deacetoxyxenicin, new cytotoxic diterpenoid from Bornean soft coral, Xenia sp. Nat. Prod. Res. 2017, 33, 808-813. [CrossRef] [PubMed]

62. Bowden, B.F.; Coll, J.C.; Willis, R.H. Studies of Australian soft corals. XXXIX. New sesquiterpene metabolites from several Xenia species (Xeniidae, Octocorallia, Anthozoa). Aust. J. Chem. 1986, 39, 1717-1722. [CrossRef]

63. Bowden, B.F.; Coll, J.C.; Engelhardt, L.M.; Heaton, A.; White, A.H. Studies of Australian soft corals. XLI structure determination of a new sesquiterpene from Xenia novae-britanniae and an investigation of a Xenia species. Aust. J. Chem. 1987, 40,1483-1489. [CrossRef]

64. Duh, C.Y.; Chien, S.C.; Song, P.Y.; Wang, S.K.; El-Gamal, A.A.H.; Dai, C.F. New cadinene sesquiterpenoids from the Formosan soft coral Xenia puerto-galerae. J. Nat. Prod. 2002, 65, 1853-1856. [CrossRef] [PubMed]

65. Shen, Y.C.; Tzeng, G.L.; Chen, M.H.; Khalil, A.T. Three new cadinene derivatives from Xenia puerto-galerae. J. Chin. Chem. Soc. 2007, 54, 1347-1352. [CrossRef]

66. Kitagawa, I.; Kobayashi, M.; Cui, Z.; Kiyota, Y.; Ohnishi, M. Marine natural products. XV. Chemical constituents of an Okinawan soft coral of Xenia sp. (Xeniidae). Chem. Pharm. Bull. 1986, 34, 4590-4596. [CrossRef]

67. Huber, T.; Weisheit, L.; Magauer, T. Synthesis of Xenia diterpenoids and related metabolites from marine organisms. Beilstein J. Org. Chem. 2015, 11, 2521-2539. [CrossRef]

68. Koido, T.; Imahara, Y.; Fukami, H. High species diversity of the soft coral family Xeniidae (Octocorallia, Alcyonacea) in the temperate region of Japan revealed by morphological and molecular analyses. ZooKeys 2019, 862, 1-22. [CrossRef]

69. Maloney, K.N.; Botts, R.T.; Davis, T.S.; Okada, B.K.; Maloney, E.M.; Leber, C.A.; Alvarado, O.; Brayton, C.; Caraballo-Rodríguez, M.A.; Chari, J.V.; et al. Cryptic species account for the seemingly idiosyncratic secondary metabolism of Sarcophyton glaucum specimens collected in Palau. J. Nat. Prod. 2020, 83, 693-705. [CrossRef]

Publisher's Note: MDPI stays neutral with regard to jurisdictional claims in published maps and institutional affiliations.

(C) 2020 by the authors. Licensee MDPI, Basel, Switzerland. This article is an open access article distributed under the terms and conditions of the Creative Commons Attribution (CC BY) license (http://creativecommons.org/licenses/by/4.0/). 